\title{
Corticotropin-Releasing Factor Receptor-1 Neurons in the Lateral Amygdala Display Selective Sensitivity to Acute and Chronic Ethanol Exposure
}

\author{
Abigail E. Agoglia, ${ }^{1,2}$ ManHua Zhu, ${ }^{3}$ Rose Ying, ${ }^{1,2}$ Harpreet Sidhu, ${ }^{4}$ Luis A. Natividad, ${ }^{5}$ Sarah A. Wolfe, ${ }^{4}$ \\ Matthew W. Buczynski, ${ }^{6}{ }^{1}$ Candice Contet, ${ }^{4}$ Loren H. Parsons, ${ }^{4}$ Marisa Roberto, ${ }^{4}$ and \\ Melissa A. Herman ${ }^{1,2}$
}

https://doi.org/10.1523/ENEURO.0420-19.2020

${ }^{1}$ Department of Pharmacology, School of Medicine, University of North Carolina at Chapel Hill, Chapel Hill, North Carolina 27599, ${ }^{2}$ Bowles Center for Alcohol Studies, School of Medicine, University of North Carolina at Chapel Hill, Chapel Hill, North Carolina 27599, ${ }^{3}$ Neuroscience Curriculum, School of Medicine, University of North Carolina at Chapel Hill, Chapel Hill, North Carolina 27599, ${ }^{4}$ Department of Neuroscience, The Scripps Research Institute, La Jolla, California 92037, 5 University of Texas at Austin, College of Pharmacy - Division of Pharmacology and Toxicology, Austin, TX 78712, and ${ }^{6}$ School of Neuroscience, Virginia Polytechnic Institute and State University, Blacksburg, Virginia 24061

\begin{abstract}
The lateral amygdala (LA) serves as the point of entry for sensory information within the amygdala complex, a structure that plays a critical role in emotional processes and has been implicated in alcohol use disorders. Within the amygdala, the corticotropin-releasing factor (CRF) system has been shown to mediate some of the effects of both stress and ethanol, but the effects of ethanol on specific CRF1 receptor circuits in the amygdala have not been fully established. We used male CRF1:GFP reporter mice to characterize CRF1-expressing $\left(\mathrm{CRF}^{+}{ }^{+}\right)$and nonexpressing $\left(\mathrm{CRF}^{-}{ }^{-}\right) \mathrm{LA}$ neurons and investigate the effects of acute and chronic ethanol exposure on these populations. The $\mathrm{CRF}^{+}$population was found to be composed predominantly of glutamatergic projection neurons with a minority subpopulation of interneurons. $\mathrm{CRF}^{+}$neurons exhibited a tonic conductance that was insensitive to acute ethanol. CRF1- neurons did not display a basal tonic conductance, but the application of acute ethanol induced a $\delta \mathrm{GABA}_{\mathrm{A}}$ receptor subunit-dependent tonic conductance and enhanced phasic GABA release onto these cells. Chronic ethanol increased $\mathrm{CRF}^{+}$neuronal excitability but did not significantly alter phasic or tonic GABA signaling in either $\mathrm{CRF}^{+}$or $\mathrm{CRF}^{-}$cells. Chronic ethanol and withdrawal also did not alter basal extracellular GABA or glutamate transmitter levels in the LA/BLA and did not alter the sensitivity of GABA or glutamate to acute ethanol-induced increases in transmitter release. Together, these results provide the first characterization of the $\mathrm{CRF} 1^{+}$ population of LA neurons and suggest mechanisms for differential acute ethanol sensitivity within this region.
\end{abstract}

Key words: alcohol; basolateral amygdala; CRF; CRF1 receptor; GABA; lateral amygdala

\section{Significance Statement}

The corticotropin-releasing factor (CRF) system is a critical component of the stress network and has been implicated in psychiatric disorders including addiction, anxiety, and depression. The present study examines CRF receptor-1 (CRF1) lateral amygdala (LA) neurons and reports differential inhibitory control and acute ethanol effects of CRF1 LA neurons compared with the unlabeled $\left(\mathrm{CRF}^{-}\right)$population. An improved understanding of CRF1 amygdala circuitry and the selective sensitivity of that circuitry to ethanol represents an important step in identifying brain region-specific neuroadaptations that occur with ethanol exposure. The present findings also have broad implications, including potential relevance to the role of CRF1 circuitry in other contexts that may provide insight into other disorders involving amygdala dysfunction, including anxiety and depression. 


\section{Introduction}

The amygdala complex has been implicated in a number of important functions, notably emotional processing of internal and external sensory stimuli and the coordination of relevant behavioral output (Pitkänen et al., 1997). Amygdala dysfunction is implicated in anxiety (Tye et al., 2011) and alcohol abuse disorders (Koob et al., 1998). The lateral amygdala (LA) serves as the entry point for sensory information and sends excitatory projections to other amygdala nuclei, including the central amygdala $(\mathrm{CeA})$ and basolateral amygdala (BLA), to facilitate stimuli processing (Sah et al., 2003; Agoglia and Herman, 2018). The LA is required for the acquisition and expression of fear learning and memory (Sears et al., 2014), and plays a crucial role in the development of anxiety-like behaviors (Rodrigues et al., 2004). Similar mechanisms may be involved in the dysregulated amygdalar activity seen in alcohol dependence (McCool et al., 2010), but the diversity of cell types within the LA complicates the interpretation of ethanol (EtOH) effects.

GABAergic neurotransmission is sensitive to acute and chronic ethanol exposure, and $\mathrm{GABA}_{\mathrm{A}}$ receptor activity is involved in ethanol tolerance and dependence. (Eckardt et al., 1998; Grobin et al., 1998; Weiner and Valenzuela, 2006). Both phasic (immediate, short-term inhibition) and tonic (persistent inhibition) GABAergic transmission within the $\mathrm{CeA}$ is sensitive to acute and chronic ethanol in a cell type-specific manner (Herman et al., 2013, 2016). The functional characteristics of $\mathrm{GABA}_{\mathrm{A}}$ receptors are determined by their subunit composition; receptors containing the $\alpha 4, \alpha 6$, and/or $\delta$ subunit are expressed extrasynaptically and mediate tonic conductance (Semyanov et al., 2004). These receptors also display an increased sensitivity to ethanol (Wallner et al., 2003; Wei et al., 2004) and may be a primary target for ethanol in the brain (Wallner et al., 2003; Mody et al., 2007), although the direct action of ethanol on tonic $\mathrm{GABA}_{\mathrm{A}}$ receptors remains controversial (Borghese and Harris, 2007; Baur et al., 2009). Tonic inhibition has been described in principal cells and local interneurons in the LA, but the receptor composition

Received October 10, 2019; accepted January 28, 2020; First published February 10, 2020.

The authors declare no competing financial interests.

Author contributions: C.C., L.H.P., M.R., and M.A.H. designed research; H.S., L.A.N., S.A.W., and M.A.H. performed research; M.W.B. contributed unpublished reagents/analytic tools; A.E.A., M.Z., R.Y., L.A.N., M.W.B., and M.A.H. analyzed data; A.E.A., M.Z., R.Y., M.W.B., C.C., and M.A.H. wrote the paper.

This work was supported by the Bowles Center for Alcohol Studies; and National Institutes of Health Grants T32-AA-007573 (A.E.A.), T32-NS-007431 (M.Z.), AA-023002 (M.A.H.), AA-011605 (M.A.H.), AA-015566 (M.R.), AA021491 (M.R.), AA-006420 (C.C., M.R.), T32-AA-007456 (S.A.W.), AA-026685 (C.C.), and AA-024952 (H.S.).

Acknowledgments: We thank Ilham Polis for technical assistance with the microdialysis experiments and Elizabeth Crofton for manuscript review.

Correspondence should be addressed to Melissa A. Herman at melissa herman@unc.edu.

https://doi.org/10.1523/ENEURO.0420-19.2020

Copyright $@ 2020$ Agoglia et al.

This is an open-access article distributed under the terms of the Creative Commons Attribution 4.0 International license, which permits unrestricted use, distribution and reproduction in any medium provided that the original work is properly attributed. mediating this tonic conductance in LA neurons is unclear (Marowsky et al., 2012).

Corticotropin-releasing factor (CRF) and the CRF receptor-1 (CRF1) are expressed throughout the amygdala (Van Pett et al., 2000; Calakos et al., 2017) and have been implicated in neuroplastic changes related to fear (Hubbard et al., 2007), anxiety (Overstreet et al., 2004; Rainnie et al., 2004), and alcohol exposure (Nie et al., 2004; Roberto et al., 2010; Herman et al., 2013; Lovinger and Roberto, 2013). Notably, activation of CRF1 receptors increases the excitability of BLA neurons to sensory input (Ugolini et al., 2008), and administration of CRF into the BLA increases activation of calcium/calmodulin-dependent protein kinase II (CaMKII)containing projection neurons (Rostkowski et al., 2013). Despite the expression of CRF and CRF1 in the LA and the relevance of the CRF system to the consequences of ethanol exposure, the specific effects of ethanol on the LA CRF1 neuronal population have not been characterized.

Previous work using a transgenic mouse line expressing green fluorescent protein (GFP) under the Crhr1 promoter (Justice et al., 2008) found that $\mathrm{CRF}^{+}{ }^{+}$and $\mathrm{CRF}^{-}$neurons within the $\mathrm{CeA}$ exhibit distinct inhibitory characteristics and differential sensitivity to acute and chronic ethanol (Herman et al., 2013, 2016). The CRF1-containing neuronal population within the LA has not been previously characterized, and could be an important determinant of LA activity and output as well as a site of action for drugs of abuse such as ethanol. The current study uses the same CRF1: GFP mice to selectively target and characterize CRF1 neurons in the LA, not to probe the effect of CRF1 activation, which will be the subject of future studies. Here, we combine electrophysiology, immunohistochemistry, and microdialysis to (1) characterize the phenotype of $\mathrm{CRF}^{+}$and $\mathrm{CRF}^{-}$neurons of the LA, (2) investigate phasic and tonic inhibitory transmission in $\mathrm{LA} \mathrm{CRF}^{+}$and $\mathrm{CRF}^{-}{ }^{-}$cells, and (3) determine the effects of acute and chronic ethanol exposure on inhibitory control within the LA.

\section{Materials and Methods}

\section{Animals}

Experiments were performed in 59 adult (age, 36 months; weight, 19-30 g) male transgenic CRF1:GFP mice that express GFP under the Crhr1 promoter, as previously described (Justice et al., 2008). Mice were bred and group housed in a temperature- and humidity-controlled 12 h light/dark facility with ad libitum access to food and water. All experiments were performed in tissue collected from mice between zeitgeber 2 and 7. All procedures were approved by the Scripps Research Institute and the University of North Carolina at Chapel Hill Institutional Animal Care and Use Committees.

\section{Electrophysiological recording}

Coronal sections $(300 \mu \mathrm{m})$ were prepared with a Leica VT1000S (Leica Microsystems) from brains that were rapidly extracted from mice after brief anesthesia (5\% isoflurane) and placed in ice-cold sucrose solution containing (in mM): sucrose 206.0; $\mathrm{KCl} 2.5 ; \mathrm{CaCl}_{2} 0.5 ; \mathrm{MgCl}_{2} 7.0$; $\mathrm{NaH}_{2} \mathrm{PO}_{4}$ 1.2; $\mathrm{NaHCO}_{3} 26$; glucose 5.0; and HEPES 5. 
After sectioning, slices were incubated in an oxygenated $\left(95 \% \mathrm{O}_{2} / 5 \% \mathrm{CO}_{2}\right)$ artificial CSF (aCSF) solution containing (in $\mathrm{mm}$ ): $\mathrm{NaCl} 130, \mathrm{KCl} 3.5, \mathrm{NaH} 2 \mathrm{PO} 41.25, \mathrm{MgSO} 4$ 1.5, $\mathrm{CaCl} 2 \mathrm{2}, \mathrm{NaHCO} 324$, and glucose 10 for $30 \mathrm{~min}$ at $37^{\circ} \mathrm{C}$, followed by $30 \mathrm{~min}$ equilibration at room temperature $\left(\mathrm{RT} ; 21-22^{\circ} \mathrm{C}\right)$. Recordings were made with patch pipettes (3-6 M' $\Omega$; Warner Instruments) filled with an intracellular solution containing (in $\mathrm{mm}$ ): $\mathrm{KCl} 145$; EGTA 5; $\mathrm{MgCl}_{2}$ 5; HEPES 10; Na-ATP 2; and Na-GTP 0.2, coupled to a Multiclamp 700B amplifier (Molecular Devices), acquired at $10 \mathrm{kHz}$, low-pass filtered at $2-5 \mathrm{kHz}$, digitized at $20 \mathrm{kHz}$ (Digidata 1440A digitizer; Molecular Devices), and stored on a computer using pClamp 10 software (Axon Instruments). Series resistance was typically $<15 \mathrm{M} \Omega$ and was continuously monitored with a hyperpolarizing $10 \mathrm{mV}$ pulse; neurons with series resistance $>15 \mathrm{M} \Omega$ or $>20 \%$ change in resistance during recording were excluded from final analysis. LA neurons containing the CRF1 receptor were identified by GFP expression and differentiated from unlabeled (GFP ${ }^{-}$) neurons using fluorescent optics and brief $(<2 \mathrm{~s})$ episcopic illumination in slices from CRF1:GFP reporter mice. Electrophysiological properties of cells were determined by pClamp 10 Clampex software online during voltage-clamp recording using a $10 \mathrm{mV}$ pulse delivered after breaking into the cell. Drugs were applied either by bath or Y-tube application for local perfusion. Recordings $\left(V_{\text {hold }}=-60 \mathrm{mV}\right)$ were performed in the presence of the glutamate receptor blockers 6,7-dinitroquinoxaline-2,3-dione (DNQX; $20 \mu \mathrm{M}$ ) and aminophosphonopentanoic acid (AP-5; $50 \mu \mathrm{M}$ ) and the $\mathrm{GABA}_{B}$ receptor antagonist CGP55845A $(1 \mu \mathrm{M})$. All recordings were conducted at room temperature, and all solutions (bath and Y-tube) were prepared and maintained at room temperature.

\section{Drugs and chemicals}

DNQX $(10 \mu \mathrm{M})$, AP-5 $(50 \mu \mathrm{M})$, and CGP55845A (1 $\mu \mathrm{M})$ were purchased from Tocris Bioscience. SR-95 531 [gabazine (GBZ); $100 \mu \mathrm{M}]$, picrotoxin $(100 \mu \mathrm{M})$, and 4,5,6,7tetrahydroisoxazolo[5,4-c]pyridin-3-ol (THIP; 1-10 $\mu \mathrm{M}$ ) were purchased from Sigma-Aldrich.

\section{Immunohistochemistry}

Mice $(n=4)$ were anesthetized with isoflurane and perfused with cold PBS followed by $4 \%$ paraformaldehyde (PFA). Brains were dissected and immersion fixed in PFA for $24 \mathrm{~h}$ at $4^{\circ} \mathrm{C}$, cryoprotected in sterile $30 \%$ sucrose in PBS for $24-48 \mathrm{~h}$ at $4^{\circ} \mathrm{C}$ or until brains sank, flash frozen in prechilled isopentane on dry ice, and stored at $-80^{\circ} \mathrm{C}$. Free-floating $35 \mu \mathrm{m}$ brain sections were obtained using a cryostat and kept at $4^{\circ} \mathrm{C}$ in PBS containing $0.01 \%$ sodium azide.

Sections were washed in PBS for 10 min at RT with gentle agitation and then blocked for $1 \mathrm{~h}$ at $\mathrm{RT}$ in blocking solution $(0.3 \%$ Triton $X-100,1 \mathrm{mg} / \mathrm{ml}$ bovine serum albumin, and $5 \%$ normal goat serum (NGS)]. Primary antibody was incubated at $4^{\circ} \mathrm{C}$ overnight with gentle agitation in $0.5 \%$ Tween-20 and 5\% NGS. The following primary antibodies were used: chicken anti-GFP (1:2000; catalog \#ab13970,
Abcam; RRID:AB_300798); rabbit anti- $\alpha 1$ and rabbit anti$\delta \mathrm{GABA}_{\mathrm{A}}$ receptor subunit $(1: 100 ; 812-\mathrm{GA} 1 \mathrm{~N}, 868 \mathrm{~A}-\mathrm{GDN}$, PhosphoSolutions); mouse anti-parvalbumin (PV; 1:1000; catalog \#235, Swant; RRID:AB_10000343); mouse anticalretinin (1:500; catalog \#6B3, Swant; RRID:AB_10000320); and mouse anti-calbindin (1:2000; catalog \#300, Swant, RRID:AB_10000347). Antibodies against native mouse protein were validated by the manufacturer with tissue from knock-out mice, with the exception of anti- $\delta \mathrm{GABA}_{\mathrm{A}}$. Next, sections were triple washed in PBS for $10 \mathrm{~min}$ at RT with gentle agitation followed by a $1 \mathrm{~h}$ secondary antibody incubation in PBS (in the dark). The following secondary antibodies were used: Alexa Fluor 488 goat anti-chicken (catalog \#A-11039, Thermo Fisher Scientific; RRID:AB 142924); Cy-3 donkey anti-rabbit (catalog \#711-165-152, Jackson ImmunoResearch; RRID:AB_2307443); and Alexa Fluor 568 goat anti-mouse (catalog \#A-11004, Thermo Fisher Scientific; RRID:AB_2534072). Sections were then washed (10 min, RT, three times) and mounted in Vectashield (catalog \#H1500, Vector Laboratories; RRID:AB_2336788).

Sections were imaged on a Zeiss LSM 780 laser-scanning confocal microscope $(10 \times$ objective, tile scanning of LA). All microscope settings were kept the same within experiments during image acquisition. The analyst was blind to the identity of the red fluorescent signal when performing cell counts, and analysis was performed manually in an unbiased manner at four anterior-posterior levels (equidistant sections located -1.00 through $-1.70 \mathrm{~mm}$ from bregma). Data are presented as the mean $\pm \mathrm{SE}$.

\section{In situ hybridization}

Mice $(n=3)$ were perfused with ice cold PBS/Z-fix (cata$\log$ \#NC9378601, Thermo Fisher Scientific) after anesthesia with isoflurane. Following perfusion, brains were dissected and immersion fixed for $24 \mathrm{~h}$ in Z-fix at $4^{\circ} \mathrm{C}$, cryoprotected in $30 \%$ sucrose in PBS for $24 \mathrm{~h}$ at $4^{\circ} \mathrm{C}$, and flash frozen in isopentane on dry ice. Brains were preliminarily stored at $-80^{\circ} \mathrm{C}$ until they were sliced on a cryostat in 20- $\mu$ m-thick sections, mounted on SuperFrost Plus slides (catalog \#1255015, Thermo Fisher Scientific), and stored at $-80^{\circ} \mathrm{C}$.

Using an RNAscope fluorescent multiplex kit (catalog \#320850, ACD), in situ hybridization was performed for Crhr1, Gfp, and S/c17a7. Target retrieval pretreatment as outlined in the manual provided by RNAscope (document \#320535, ACD) was performed by first briefly washing prepared slides in PBS. Next slides were submerged in prewarmed target retrieval buffer (catalog \#322000, ACD) and kept at a constant temperature between $95^{\circ} \mathrm{C}$ and $98^{\circ} \mathrm{C}$ for $10 \mathrm{~min}$. Slides were then removed and immediately rinsed in distilled water twice, and then dehydrated with $100 \%$ ethanol. After dehydrations, slices were demarcated with a hydrophobic barrier pen (catalog \#310018, ACD) and digested with Protease IV for $20 \mathrm{~min}$ at $40^{\circ} \mathrm{C}$ in a hybridization oven. Next, the RNAscope Fluorescent Multiplex Reagent Kit User Manual (document \#320293, ACD) was followed entirely. Last, slides were mounted with Vectashield with DAPI (catalog \#NC9029229, Thermo Fisher Scientific). The probes used 
were Crhr1 (probe target region 207-813; catalog \#418011-C2), Slc17a7 (probe target region 464-1415; catalog \#416631-C1), eGFP (probe target region 6281352; catalog \#400281), and a negative control (catalog \#320751), all from ACD.

Slides were imaged on a Zeiss LSM 780 laser-scanning confocal microscope (40× oil-immersion, $1024 \times 10^{24}$; of LA at approximately $-1.46 \mathrm{~mm}$ from bregma; $5 \mu \mathrm{m} \mathrm{z-}$ stacks). All microscope settings were kept the same within experiments during image acquisition. Background was subtracted from images based on the negative control for each probe, and signal intensity present in DAPIlabeled nuclei after background subtracted denoted positive cells. To perform quantification, ImageJ was used to manually count DAPI-labeled nuclei expressing fluorescently labeled probes in the region of interest (ROI). Next, the percentage of nuclei positive for one or both probes and the percentage of signal colocalization were calculated. The percentage of $\mathrm{Crhr}^{+}$nuclei expressing a marker of interest was determined by dividing the number of colabeled nuclei by the total number of $\mathrm{Crhr}^{+}$nuclei. Quantification was performed on three to four images (approximately $-1.46 \mathrm{~mm}$ from bregma) from each mouse in an unbiased manner as probe fluorescence was quantified blindly. Brightness/contrast and pixel dilation are the same for all representative images.

\section{Chronic intermittent ethanol vapor inhalation}

Mice were placed in ethanol inhalation chambers (La Jolla Alcohol Research) and exposed to chronic intermittent ethanol (CIE) vapor (16 h) followed by air (8 h) daily for 4 consecutive days/week for a period of 4-5 weeks (Herman et al., 2016). Before each vapor exposure, CIE mice were injected with a solution of ethanol $(1.5 \mathrm{~g} / \mathrm{kg})$ and pyrazole ( $1 \mathrm{mmol} / \mathrm{kg}$, i.p.), an alcohol dehydrogenase inhibitor, to initiate intoxication and maintain constant blood alcohol levels (BALs). Control mice were exposed to room air and received an injection of pyrazole $(1 \mathrm{mmol} /$ $\mathrm{kg}$, i.p.) at the onset of each ethanol vapor exposure. Ethanol drip rate and air flow were adjusted so as to yield BALs averaging 100-250 mg/dl. BALs were measured throughout exposure using an Analox GM7 analyzer. Average BALs for the CIE mice included in electrophysiological recordings were $174.6 \pm 15.5 \mathrm{mg} / \mathrm{dl}$. Average BALs for CIE mice in microdialysis experiments were $162.7 \pm$ $16.5 \mathrm{mg} / \mathrm{dl}$. Terminal BALs were also determined at the time of death when mice were killed immediately after their last ethanol vapor exposure (CIE mice). Another group of mice underwent 3-7 d of withdrawal after their last vapor exposure before being killed (CIE-WD mice).

\section{Microdialysis}

Mice $(n=11)$ were unilaterally implanted with custom fabricated microdialysis probes $(0.5 \mathrm{~mm}$ regenerated cellulose) aimed at the LA (from bregma: anteroposterior, $-1.5 \mathrm{~mm}$; mediolateral, $\pm 2.9 \mathrm{~mm}$; dorsoventral, $-4.1 \mathrm{~mm}$ from dura). However, as some penetrance into BLA is possible, microdialysis results are described throughout as LA/BLA. Mice were perfused with aCSF at $0.2 \mu \mathrm{l} / \mathrm{min}$ and allowed to recover overnight, as previously described (Pavon et al., 2018, 2019). The following morning, the flow rate was increased to $0.6 \mu \mathrm{l} / \mathrm{min}$ and allowed to equilibrate for 60 min prior to collection. Dialysate samples were collected at $15 \mathrm{~min}$ intervals during a $1.5 \mathrm{~h}$ baseline period. Ethanol (1 M) was added to the aCSF perfusate solution for reverse dialysis through the probe, and samples were collected for an additional $1.5 \mathrm{~h}$ during the local ethanol exposure period. This dose of ethanol was chosen for consistency with prior experiments using reverse dialysis in rodents, where $1 \mathrm{~m}$ was found to induce maximal changes in extracellular GABA and glutamate levels (Roberto et al., 2004a,b).

Quantification of neurotransmitters was performed using triple liquid chromatography quadrupole mass spectrometry methods as previously described (Song et al., 2012; Buczynski et al., 2016). Briefly, microdialysate samples $(5 \mu \mathrm{l})$ were derivatized with $100 \mathrm{~mm}$ borate $(5 \mu \mathrm{l}), 2 \%$ benzoyl chloride ( $2 \mu \mathrm{l}$, in acetonitrile), and $1 \%$ formic acid $(2 \mu \mathrm{l})$, and were subsequently spiked with benzoylated ${ }^{13} \mathrm{C}_{6}$-labeled internal standards $(5 \mu \mathrm{l}$, in $98 \% \mathrm{v} / \mathrm{v}$ ACN, $1 \%$ formic acid, and $\left.1 \% \mathrm{H}_{2} \mathrm{O}\right)$. Samples $\left(10 \mu \mathrm{l}, 4^{\circ} \mathrm{C}\right)$ were separated by high-performance liquid chromatography and analyzed by positive-ion mode tandem quadrupole mass spectrometry (catalog \#6460 QQQ, Agilent) using multiple-reaction monitoring. The following neurotransmitters were quantified using the standard isotope dilution method (precursor $\rightarrow$ product): the amino acids aspartate $(238 \rightarrow 105)$, GABA $(208 \rightarrow 105)$, glutamate $(252 \rightarrow$ $105)$, glutamine $(251 \rightarrow 105)$, glycine $(180 \rightarrow 105)$, serine $(210 \rightarrow 105)$, and taurine $(230 \rightarrow 105)$. Baseline concentrations were expressed as an absolute value (nanomolar), while changes produced by ethanol reverse dialysis were expressed as relative values (percentage of baseline) over time.

\section{Statistical analysis}

Membrane characteristics and excitability were compared between groups using a two-tailed $t$ test or a oneway ANOVA, where appropriate. Frequency, amplitude, and decay of spontaneous IPSCs (sIPSCs) were analyzed and visually confirmed using a semiautomated thresholdbased mini detection software (Mini Analysis, Synaptosoft). sIPSC characteristics were determined from baseline and experimental drug conditions containing a minimum of 60 events (time period of analysis varied as a product of individual event frequency). All detected events were used for analysis, and superimposed events were eliminated. Tonic conductance was determined using Clampfit 10.2 (Molecular Devices) and a previously described method (Belelli et al., 2009) in which the mean holding current (i.e., the current required to maintain the $-60 \mathrm{mV}$ membrane potential) was obtained by a Gaussian fit to an all-points histogram over a 5 s interval. The all-points histogram was constrained to eliminate the contribution of sIPSCs to the holding current. Drug responses were quantified as the difference in holding current between baseline and experimental conditions. Events were analyzed for independent significance using a one-sample $t$ test and compared using a two-tailed $t$ 
test for independent samples, a paired two-tailed $t$ test for comparisons made within the same recording, and a one-way ANOVA for comparisons made among three or more groups. In the microdialysis experiments, average baseline concentrations of glutamate and GABA were compared in CIE-WD versus AIR controls using twotailed $t$ tests. To examine the effects of acute ethanol administration on LA/BLA dialysate, two-way repeatedmeasures ANOVA (exposure condition $\times$ time) was used to compare air to CIE-WD mice before and after reverse dialysis of ethanol. All statistical analyses were performed using Prism version 5.02 (GraphPad Software). Data are presented as mean \pm SE. In all cases, $p<0.05$ was the criterion for statistical significance.

\section{Results}

\section{Phenotype of CRF1 ${ }^{+}$LA neurons}

To validate the fidelity of the CRF1:GFP expression in the LA, we used the RNAscope assay $(n=11$ images from three mice) to examine colocalization of Crhr1, the transcript for CRF1, and Gfp, the transcript for green fluorescent protein (Fig. 1A). The number of positive nuclei in the
ROI was consistent between groups (Fig. 1B). Approximately $74 \%$ of $\mathrm{Crhr}^{+}$neurons coexpress Gfp and $84 \%$ of $\mathrm{Gfp}^{+}$neurons coexpress Crhr1 (Fig. 1C), indicating substantial penetrance and fidelity, respectively. To identify the phenotype of $\mathrm{CRF}^{+}{ }^{+}$neurons in the LA, we performed in situ hybridization in brain sections from CRF1: GFP mice ( $n=10$ images from three mice) to examine colocalization of Crhr1 and S/c17a7, the transcript for VGluT1. Consistent with GFP expression and the established glutamatergic makeup of the BLA, Crhr1 and Slc17a7 were similarly expressed in the LA (Fig. 1D-F). The number of positive nuclei counted in the ROI was not significantly different between Slc17a7 ${ }^{+}$and $\mathrm{Crhr}^{+}$(Fig. 1G). Approximately $60 \%$ of $S / c 17 a 7^{+}$neurons coexpress Crhr1, and $\sim 80 \%$ of $C r h r 1^{+}$neurons coexpress Slc17a7 (Fig. $1 H$ ). These data suggest that $\mathrm{Crhr} 1^{+}$neurons make up a subpopulation of LA glutamatergic cells and that the majority of $\mathrm{Crhr}^{+}$LA neurons are glutamatergic.

The LA is composed of glutamatergic projection neurons as well as local GABAergic interneurons (Sosulina et al., 2006). The results of the in situ experiments indicated that a subpopulation of the $\mathrm{CRF} 1^{+}$neurons of the LA do not express Slc17a7, suggesting that these neurons are
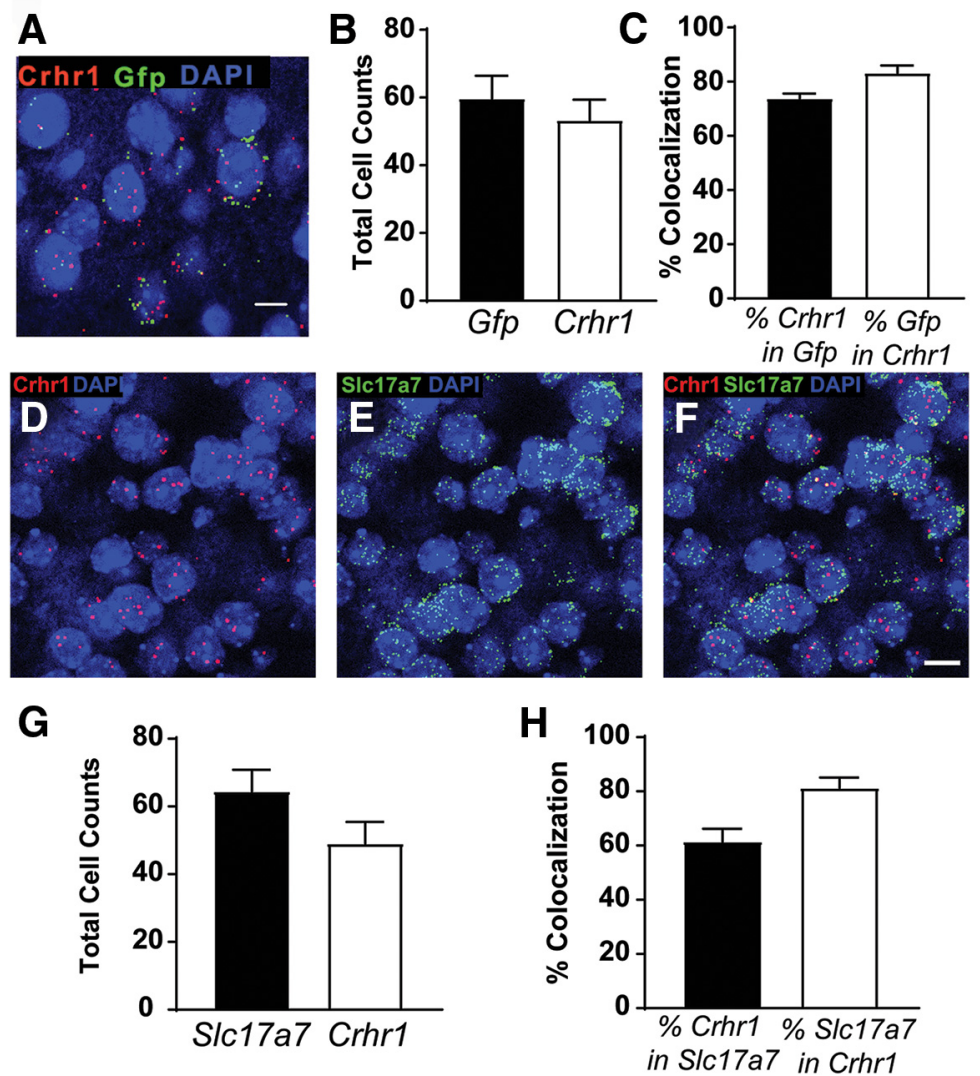

Figure 1. Glutamate transporter expression in CRF1 lateral amygdala neurons. $\boldsymbol{A}$, Representative merged image showing Crhr1, Gfp, and DAPI in the LA. Scale bar, $10 \mu \mathrm{m}$. B, Summary of the total number of $\mathrm{Gfp}^{+}$and Crhr $1^{+}$nuclei in the ROI (1024 $\times 10^{24}$; $40 \times$ ) in the LA of 11 images from 3 mice. C, Graph of the percentage of nuclei coexpressing Crhr1 in Gfp ${ }^{+}$nuclei (black bar), and the percentage of nuclei coexpressing Gfp in Crhr1 ${ }^{+}$nuclei (white bar). $\boldsymbol{D}-\boldsymbol{F}$, Representative images in the LA are shown for Crhr1 and DAPI (D); S/c17a7 and DAPI (E); and the merged imaged of Crhr1, S/c17a7, and DAPI $(\boldsymbol{F}$; Crhr1=red fluorescence, $S / c 17 a 7=$ green fluorescence, and DAPI $=$ blue fluorescence). Scale bar, $10 \mu \mathrm{m}$. G, Summary of the total number of $C r h r 1^{+}$and $S / c 17 a 7^{+}$nuclei in the ROI $\left(1024 \times 10^{24} ; 40 \times\right)$ in the LA of 10 images from 3 CRF1:GFP mice. $\boldsymbol{H}$, Graph of the percent of nuclei coexpressing Crhr1 in S/c17a $7^{+}$nuclei (black bar) and nuclei coexpressing S/c17a7 in Crhr1+ (white bar). 
not glutamatergic but may express calcium binding proteins (CBPs) associated with GABAergic interneurons. Work by Calakos et al. (2017) reported that the majority of PV-containing neurons in the BLA also expressed CRF1, but the expression of CBPs in $\mathrm{CRF}^{+}{ }^{+}$neurons of the LA is unknown. We examined PV and GFP colocalization in the LA of CRF1:GFP mice ( $n=16$ sections from four mice) as well as calbindin (CB) and calretinin (CR). For the purpose of clarity, we refer to $\mathrm{GFP}^{+}$and $\mathrm{GFP}^{-}$neurons throughout as $\mathrm{CRF}_{1}{ }^{+}$and $\mathrm{CRF}^{-}{ }^{-}$, respectively. We observed expression of $C B, C R$, and $P V$ interspersed with GFP in the LA (Fig. $2 A-C$ ), but there were more $\mathrm{CRF}^{+}$cells than $\mathrm{CBP}$ containing cells (Fig. 2D). Consistent with Calakos et al. (2017), we observed that a substantial percentage $(\sim 80 \%)$ of $\mathrm{CBP}^{+}$cells also expressed GFP (Fig. $2 E$ ), suggesting that the majority of LA neurons that express CBPs
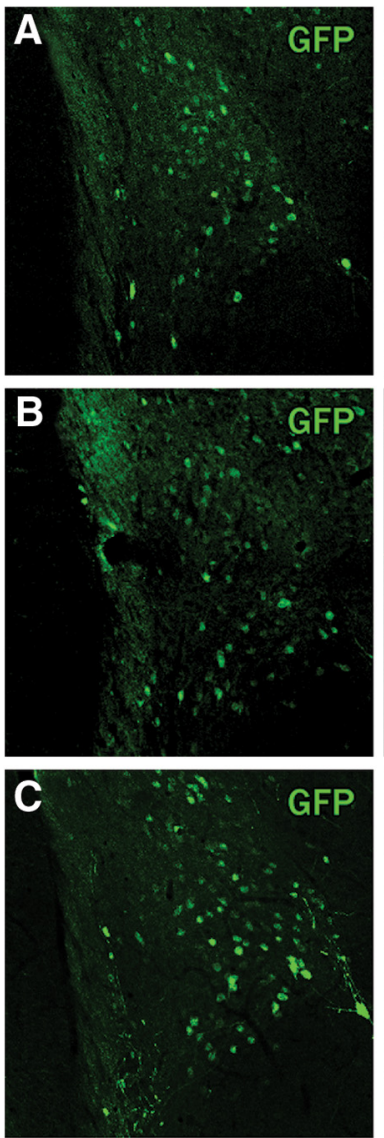

D

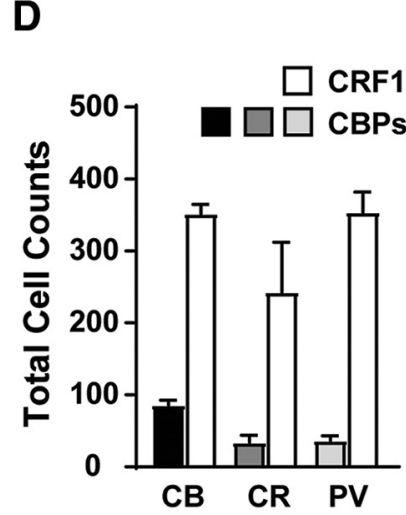

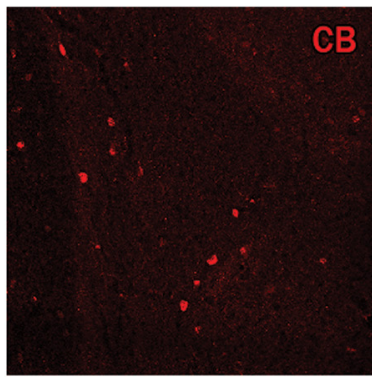
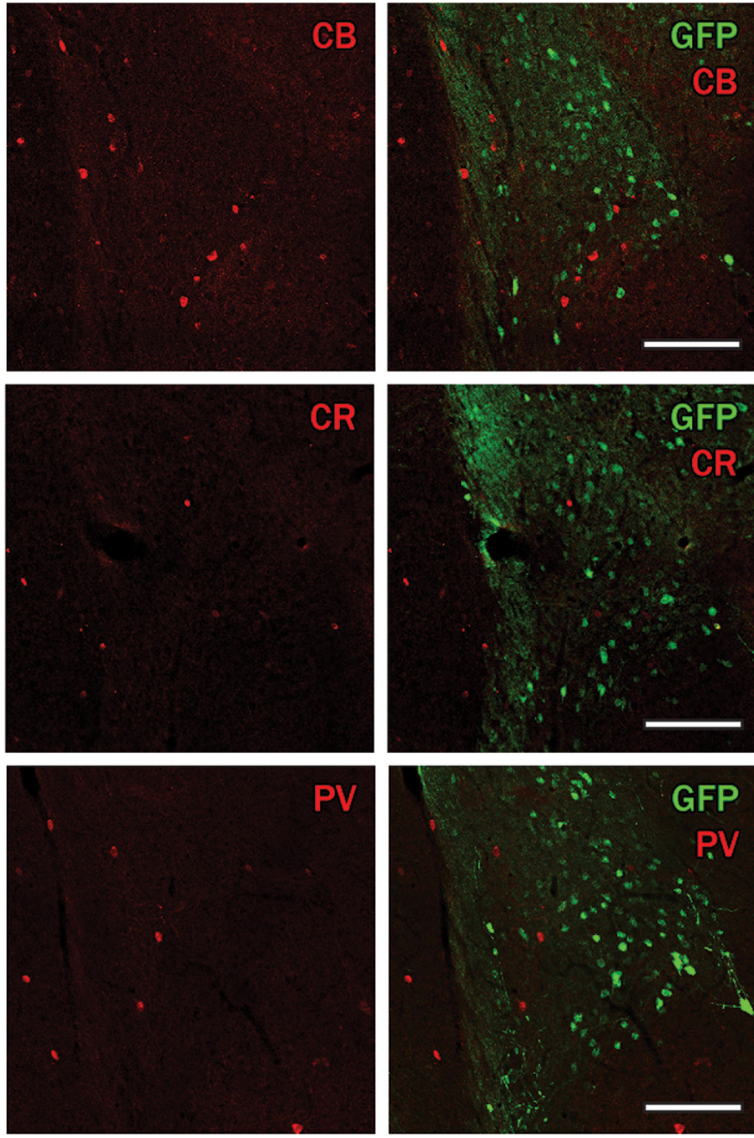

E
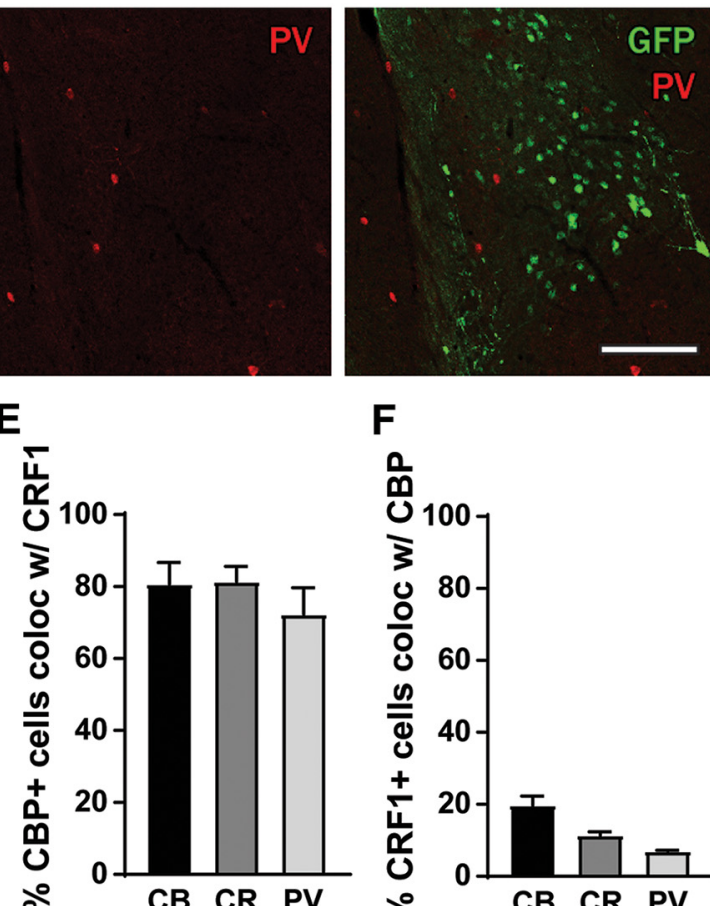

$F$

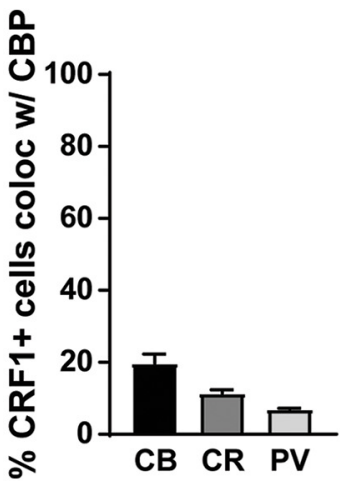

Figure 2. Calcium binding protein expression in $\mathrm{CRF}^{+}$and $\mathrm{CRF} 1^{-}$lateral amygdala neurons. $\boldsymbol{A}$, Photomicrograph (10×) of GFP expression (green fluorescence, left), calbindin expression (red fluorescence, center), and merge (right). Scale bar, $100 \mu \mathrm{m}$. $\boldsymbol{B}$, Photomicrograph $(10 \times)$ of GFP expression (green fluorescence, left), calretinin expression (red fluorescence, center), and merge (right). Scale bar, $100 \mu \mathrm{m}$. C, Photomicrograph (10×) of GFP expression (green fluorescence, left), parvalbumin expression (red fluorescence, middle), and merge (right). Scale bar, $100 \mu \mathrm{m}$. $\boldsymbol{D}$, Summary of total cells expressing CRF1 (GFP) and CBPs, $n=16$ sections from 4 mice. $\boldsymbol{E}$, Percentage of $\mathrm{CBP}^{+}$cells that coexpress CRF1. $\boldsymbol{F}$, Percentage of $\mathrm{CRF}^{+}{ }^{+}$cells that coexpress $\mathrm{CBPs}$. 
also contain CRF1. However, the percentage of $\mathrm{CRF}^{+}$ neurons that contain CBPs was much lower (<20\%; Fig. $2 F$ ), suggesting that the majority of $\mathrm{CRF}^{+}{ }^{+}$neurons are likely not interneurons that express these calcium binding proteins. Together, the results of the in situ and immunohistochemistry experiments identify the $\mathrm{CRF} 1^{+}$neurons of the LA as a mostly ( $80 \%)$ glutamatergic population with a smaller ( $20 \%)$ population of neurons that express CBPs (potentially GABAergic interneurons).

\section{Membrane properties and excitability}

LA neurons were identified and targeted for electrophysiological recording based on GFP expression. $\mathrm{CRF}^{+}$neurons $(n=28$ cells from 14 mice) possessed a significantly smaller membrane capacitance $\left(t_{(54)}=2.96\right.$; $p=0.0046$ by unpaired $t$ test, $21.84 \pm 7.39 \mathrm{pF}$ effect size; $95 \%$ confidence interval, -36.65 to -7.02$)$, increased membrane resistance $\left(t_{(30)}=2.34 ; p=0.0260\right.$ by unpaired $t$ test; $99.46 \pm 42.48 \mathrm{mV}$ effect size; $95 \%$ confidence interval, -186.2 to -12.71$)$, lower time constant $\left(t_{(54)}=3.08\right.$; $p=0.0033$ by unpaired $t$ test; $226 \pm 73.56 \mathrm{~ms}$ effect size; $95 \%$ confidence interval, -373.6 to -78.69$)$, and higher resting membrane potential $\left(t_{(54)}=3.95 ; p=0.0002\right.$ by unpaired $t$ test; $9.114 \pm 2.31 \mathrm{mV}$ effect size; $95 \%$ confidence interval, 4.49-13.74) compared with $\mathrm{CRF}^{-}$neurons ( $n=28$ cells from 15 mice; Fig. $3 A$ ). Whole-cell currentclamp recordings and a step protocol consisting of hyperpolarizing $(-60 \mathrm{pA})$ to depolarizing (100 pA; Fig. 3B,C) current injections were used to examine the spiking properties of $\mathrm{CRF}^{+}{ }^{+}$and $\mathrm{CRF}^{-}{ }^{-} \mathrm{LA}$ neurons. The large majority (90\%) of $\mathrm{CRF}^{+}{ }^{+}$neurons exhibited spike accommodation (Fig. 3B, bottom), whereas $\mathrm{CRF}^{-}$neurons were more variable (52\% accommodating; Fig. 3C, bottom). We observed no significant differences in rheobase

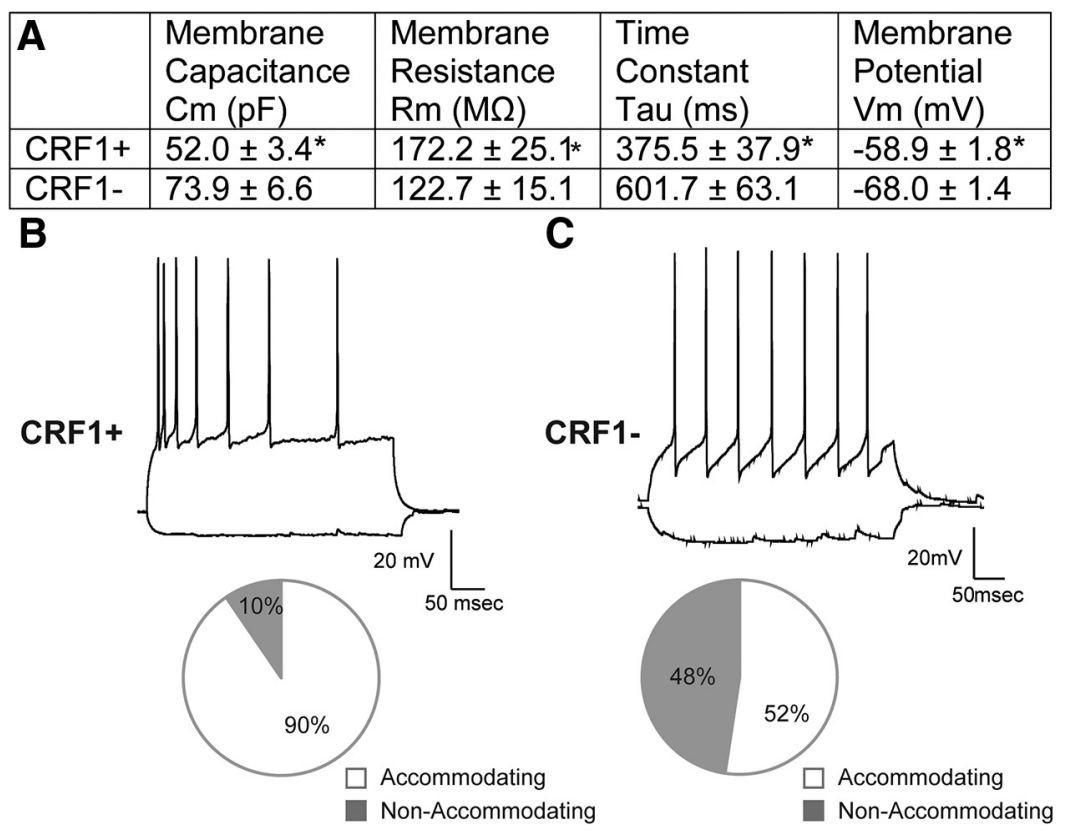

D

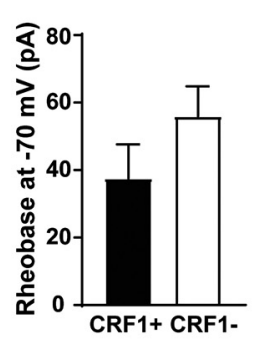

E
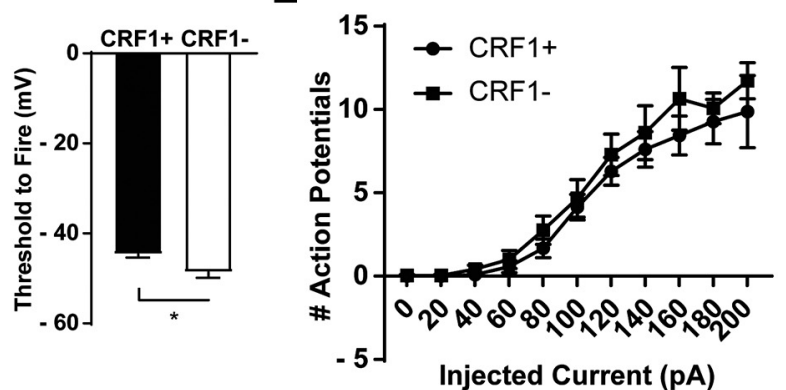

Figure 3. Membrane characteristics and excitability of $\mathrm{CRF}^{+}$and $\mathrm{CRF}^{-}$lateral amygdala neurons. $\boldsymbol{A}$, Summary of membrane characteristics of $\mathrm{CRF}^{+}(n=28)$ and $\mathrm{CRF}^{-}(n=28)$ LA cells. $\boldsymbol{B}$, Representative current-clamp recording of LA CRF1 ${ }^{+}$neuron action potentials elicited by $100 \mathrm{pA}$ current injection (top) and the relative proportion of CRF1 ${ }^{+}$LA neurons displaying spike accommodation with current injection (bottom). $\boldsymbol{C}$, Representative current-clamp recording of LA CRF1- neuron action potentials elicited by $100 \mathrm{pA}$ current injection (top) and the relative proportion of CRF1 ${ }^{-}$LA neurons displaying spike accommodation with current injection (bottom). $\boldsymbol{D}$, Summary of rheobase at $-70 \mathrm{mV}$ (left) and the threshold to fire (right) of $\mathrm{CRF} 1^{+}$and $\mathrm{CRF} 1^{-} \mathrm{LA}$ neurons. $* p<0.05$ by unpaired $t$ test comparing $\mathrm{CRF}^{+}{ }^{+}$to $\mathrm{CRF}^{-}$cells. $E$, Summary of action potentials by current injection in $\mathrm{CRF} 1^{+}$and $\mathrm{CRF} 1^{-} \mathrm{LA}$ neurons. 
between $\mathrm{CRF}^{+}{ }^{+}(37.52 \pm 10.11 \mathrm{pA})$ and $\mathrm{CRF}^{-}$neurons (55.94 \pm 8.90 pA; Fig. 3D, left); however, we did observe a significantly lower threshold to fire in $\mathrm{CRF}^{-}$neurons $(-48.64 \pm 1.25 \mathrm{pA})$ versus $\mathrm{CRF}^{+}$neurons $(-44.61 \pm$ $0.78 \mathrm{pA} ; t_{(40)}=2.73 ; p=0.0093$; effect size, $4.03 \pm 1.48 \mathrm{pA}$; $95 \%$ confidence interval, -7.01 to -1.048 ; Fig. $3 D$, right). In addition, we found no differences in action potentials elicited by ascending current injection between $\mathrm{CRF}^{+}$and $\mathrm{CRF}^{-}$neurons (Fig. 3E).

\section{Phasic and tonic inhibitory transmission}

Whole-cell voltage-clamp recordings of sIPSCs were performed to assess baseline phasic inhibitory transmission. $\mathrm{CRF}^{+}$neurons had a significantly higher average baseline sIPSC frequency $(9.0 \pm 1.8 \mathrm{~Hz} ; n=7$ cells from six mice; Fig. 4A,B) compared with $\mathrm{CRF}^{-}$neurons $\left(3.3 \pm 0.6 \mathrm{~Hz} ; t_{(14)}=3.30 ; p=0.0053\right.$ by unpaired $t$ test; $5.71 \pm 1.73 \mathrm{~Hz}$ effect size with $95 \%$ confidence interval of 2.00-9.42; $n=9$ cells from five mice; Fig. $4 A, B$ ), and no

\section{A}

CRF1+

CRF1-
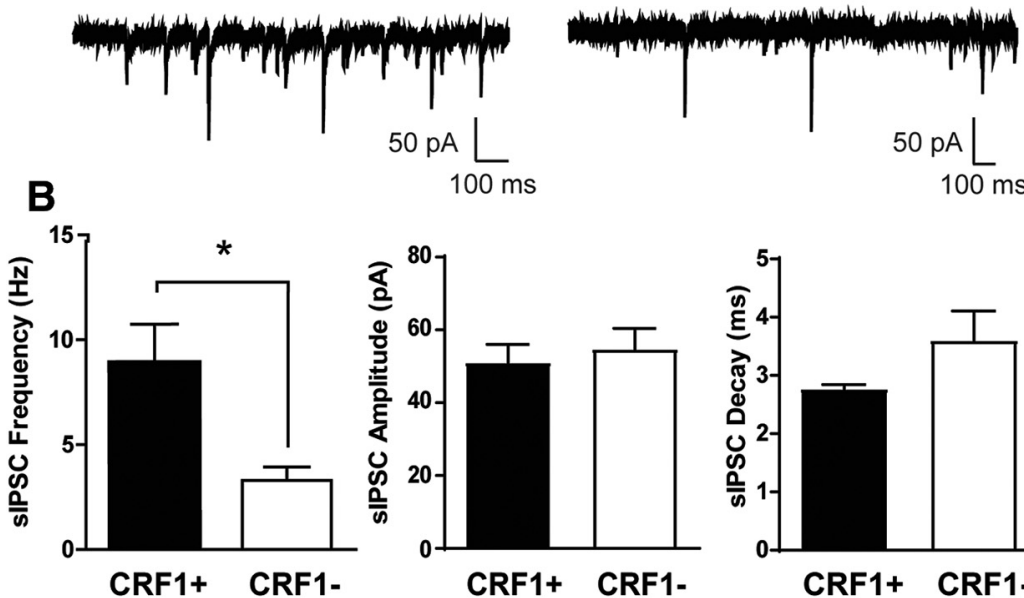

$100 \mathrm{~ms}$

$100 \mathrm{~ms}$
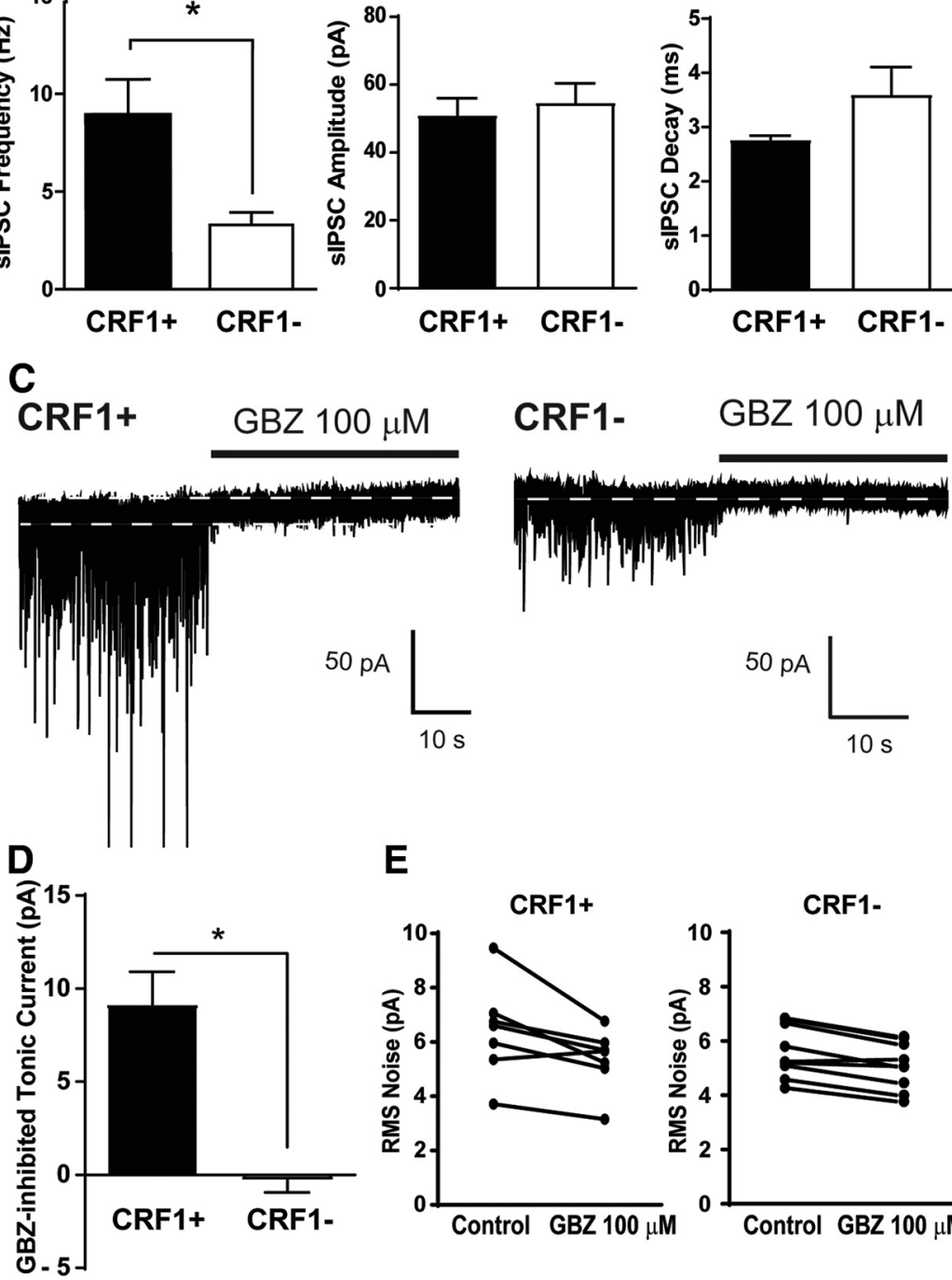

CRF1-

\section{GBZ $100 \mu \mathrm{M}$}
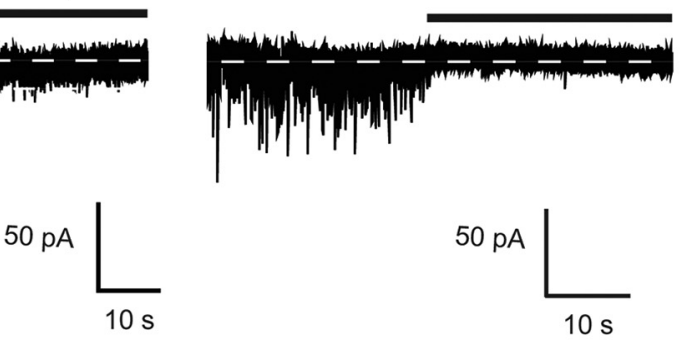

E
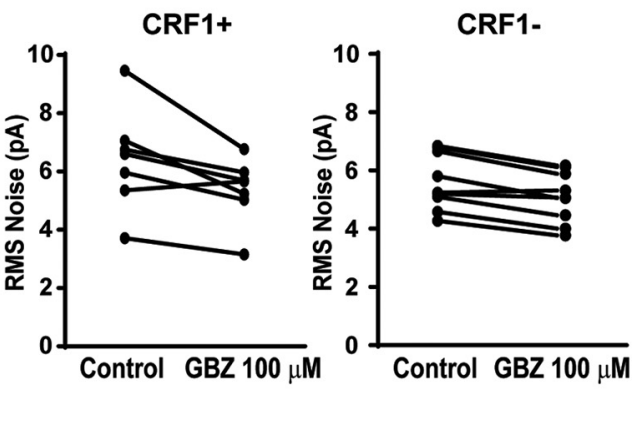

Figure 4. Phasic and tonic inhibitory transmission in CRF1 lateral amygdala neurons. $\boldsymbol{A}$, Representative voltage-clamp recording of a $\mathrm{CRF}^{+}$cell (left) and a CRF1 ${ }^{-}$cell (right). B, Summary of sIPSC frequency (left), amplitude (center), and decay (right) of CRF1 ${ }^{+}$and $\mathrm{CRF}^{-}$cells. $* p<0.05$ by unpaired $t$ test comparing CRF1 ${ }^{+}$to $\mathrm{CRF} 1-$ cells. $\boldsymbol{C}$, Representative voltage-clamp recording of a CRF1 ${ }^{+}$ cell (left) and a CRF1- cell (right) during GBZ superfusion $(100 \mu \mathrm{M})$. White dashed line indicates level of holding current before and after GBZ superfusion. $\boldsymbol{D}$, Summary of the tonic current revealed by gabazine. $* p<0.05$ by unpaired $t$ test comparing CRF1 ${ }^{+}$to $\mathrm{CRF}^{-}$cells. $\boldsymbol{E}$, Summary of the change in rms noise induced by gabazine superfusion in $\mathrm{CRF} 1^{+}$(left) and CRF1 ${ }^{-}$(right) cells. 
difference in sIPSC amplitude $(51.01 \pm 5.0$ and $54.7 \pm$ $5.7 \mathrm{pA} ; p=0.64$; Fig. $4 A, B)$, decay $(2.77 \pm 0.08$ and $3.60 \pm$ $0.5 \mathrm{~ms} ; p=0.17$; Fig. $4 A, B)$, or rise time $(1.61 \pm 0.12$ and $1.58 \pm 0.16 \mathrm{~ms} ; p=0.88$ ) between $\mathrm{CRF}^{+}{ }^{+}$and $\mathrm{CRF}^{-}{ }^{-} \mathrm{LA}$ neurons, respectively.

We assessed tonic conductance in $\mathrm{CRF}^{+}{ }^{+}(n=7$ cells from five mice) and $\mathrm{CRF}^{-}$( $n=9$ cells from five mice) LA neurons using whole-cell voltage-clamp recordings. The basal holding current was $-28.32 \pm 20.67 \mathrm{pA}$ in $\mathrm{CRF}^{+}$ neurons and $-17.19 \pm 14.65 \mathrm{pA}$ in $\mathrm{CRF}^{-}$neurons. $\mathrm{A}$ $\mathrm{GABA}_{A}$ receptor-mediated tonic current was defined as the difference in holding current (i.e., the current required to maintain the neuron at $-60 \mathrm{mV}$ ) before and after application of a $\mathrm{GABA}_{A}$ receptor antagonist. Focal application of the $\mathrm{GABA}_{\mathrm{A}}$ receptor antagonist GBZ $(100 \mu \mathrm{M})$ produced a significant reduction in holding current in $\mathrm{CRF} 1^{+}$neurons $\left(9.2 \pm 1.8 \mathrm{pA}, n=7\right.$; Fig. $4 C$, left trace, $4 D ; t_{(14)}=5.56$, $p=0.002$ by one-sample $t$ test; $9.45 \pm 1.70$ pA effect size; 95\% confidence interval, 5.81-13.09) and a reduction in the amplitude of the holding current or root mean square (rms) noise $\left(6.4 \pm 0.7-5.4 \pm 0.4 \mathrm{pA}\right.$; Fig. $4 E$, left; $t_{(6)}=2.93$, $p=0.0264$ by paired $t$ test; $1.06 \pm 0.364 \mathrm{pA}$ effect size; 95\% confidence interval, 0.17-1.94). In CRF1- neurons, focal application of GBZ $(100 \mu \mathrm{M})$ produced no change in holding current $(-0.3 \pm 0.6 \mathrm{pA}, n=9$; Fig. $4 C$, right trace, $D ; p=0.6568$ by one-sample $t$ test) and a reduction in rms noise of a much smaller magnitude (5.6 $\pm 0.3-$ $5.1 \pm 0.3 \mathrm{pA}$; Fig. $4 E$, right; $t_{(8)}=5.24, p=0.0008$ by paired $t$ test; $0.51 \pm 0.10 \mathrm{pA}$ effect size; $95 \%$ confidence interval, 0.29-0.74). The reduction in holding current was significantly greater in $\mathrm{CRF}^{+}$neurons compared with $\mathrm{CRF1}^{-}$neurons (Fig. 4D; $t_{(14)}=5.56, p=0.0001$ by unpaired $t$ test; $9.45 \pm 1.70 \mathrm{pA}$ effect size; $95 \%$ confidence interval, 5.81-13.09).

\section{Expression of $\mathrm{GABA}_{\mathrm{A}}$ receptor subunits}

The phasic and tonic conductance of $\mathrm{GABA}_{A}$ receptors is dependent on specific subunit configurations and/or expression. We performed double-label immunohistochemical studies examining $\alpha 1$ and $\delta \mathrm{GABA}_{\mathrm{A}}$ receptor subunit expression in $\mathrm{CRF}^{+}{ }^{+}$and $\mathrm{CRF}^{-}$neurons in the LA ( $n=12$ sections from four mice). The LA contains a significant number of $\mathrm{CRF}^{+}$cells, in contrast with sparse GFP expression in the BLA (Fig. 5A,D). The $\alpha 1 \mathrm{GABA}_{\mathrm{A}}$ receptor subunit has dense expression in the LA (Fig. 5B) and displays colocalization with GFP (Fig. 5C), indicating expression in the majority of $\mathrm{CRF}^{+}{ }^{+}$neurons. In contrast, $\delta \mathrm{GABA}_{\mathrm{A}}$ receptor subunit expression was greater in the body of the BLA than in the LA (Fig. 5E) and displays minimal colocalization with GFP (Fig. 5F), indicating little to no expression in $\mathrm{CRF}^{+}{ }^{+}$neurons in the LA.

The $\delta$ subunit is associated with tonic conductance in a number of brain areas, including the hippocampus, cerebellum, cortex, and amygdala (Saxena and Macdonald, 1996; Stell et al., 2003; Krook-Magnuson and Huntsman, 2005). Thus, we examined the functional contribution of $\delta$ subunit-containing $\mathrm{GABA}_{\mathrm{A}}$ receptors in the LA using the $\delta$ subunit-preferring agonist THIP $(5 \mu \mathrm{M})$. Focal application of THIP produced a modest increase in holding current in
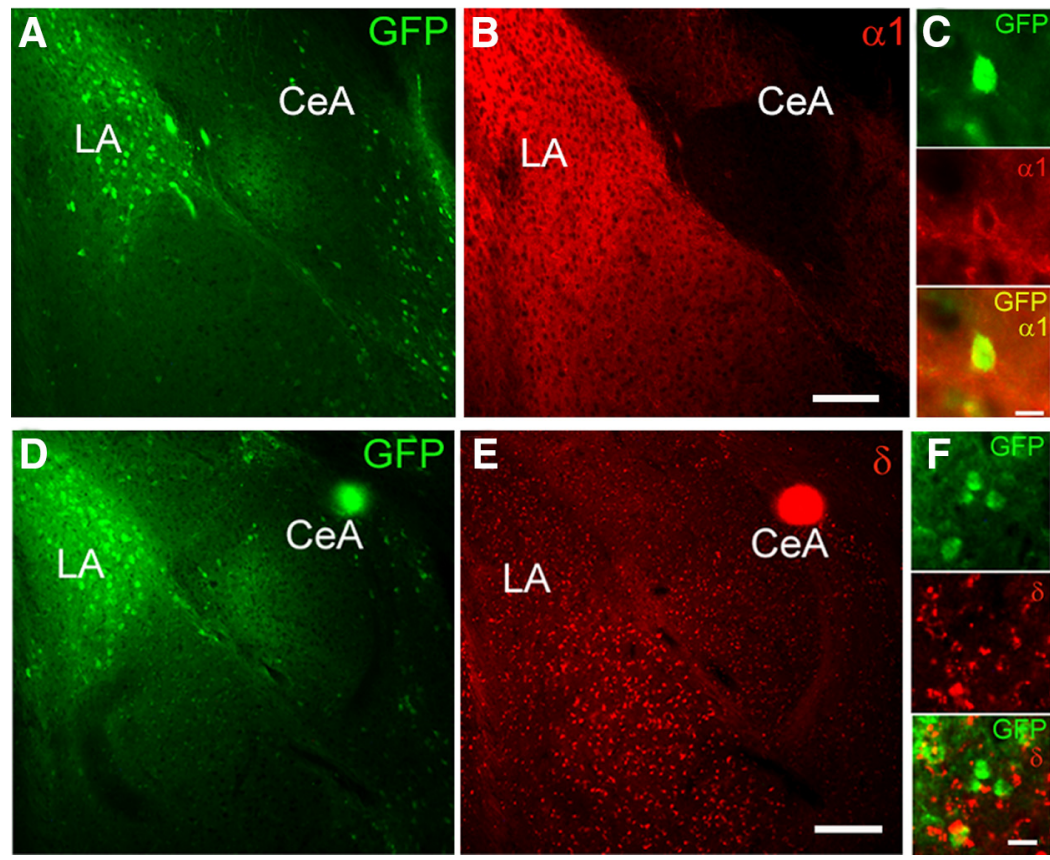

Figure 5. $\mathrm{GABA}_{\mathrm{A}}$ subunit expression in $\mathrm{CRF}^{+}$and $\mathrm{CRF}^{-}$lateral amygdala neurons. $\boldsymbol{A}$, Photomicrograph $(10 \times)$ of $\mathrm{GFP}$ expression (green fluorescence) in LA. B, Photomicrograph $(10 \times)$ of $\alpha 1 \mathrm{GABA}_{\mathrm{A}}$ receptor subunit expression (red fluorescence) in LA. Scale bar, $100 \mu \mathrm{m}$. C. Photomicrograph (60×) of GFP expression (top), $\alpha 1$ expression (center), and merge (bottom) in LA highlighting a single cell exhibiting coexpression of GFP and $\alpha 1$. Scale bar, $10 \mu \mathrm{m}$. $\boldsymbol{D}$, Photomicrograph (10×) of GFP expression (green fluorescence) in LA. $\boldsymbol{E}$, Photomicrograph $(10 \times)$ of $\delta \mathrm{GABA}_{\mathrm{A}}$ receptor subunit expression (red fluorescence) in LA. Scale bar, $100 \mu \mathrm{m}$. $\boldsymbol{F}$, Photomicrograph $(60 \times)$ of GFP expression (top), $\delta$ expression (center), and merge (bottom) in LA. Scale bar, $10 \mu \mathrm{m}$. 
A

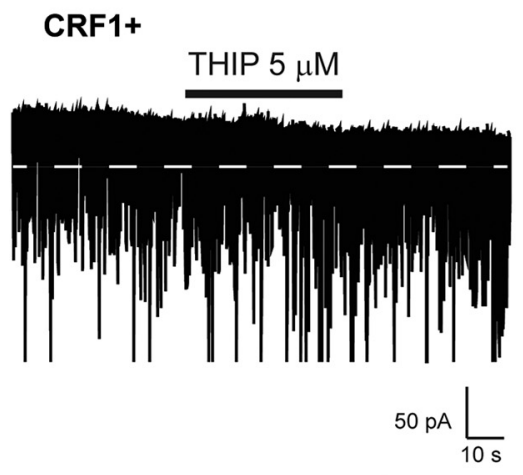

CRF1-

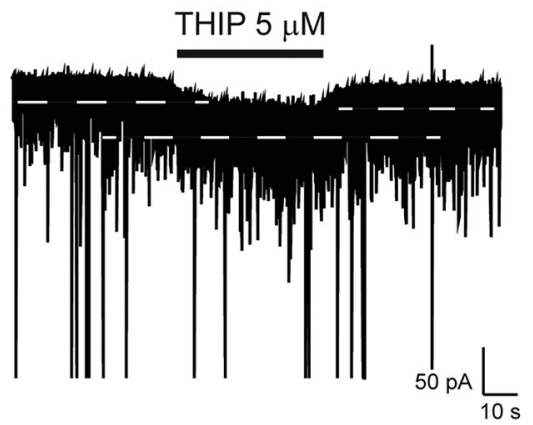

B

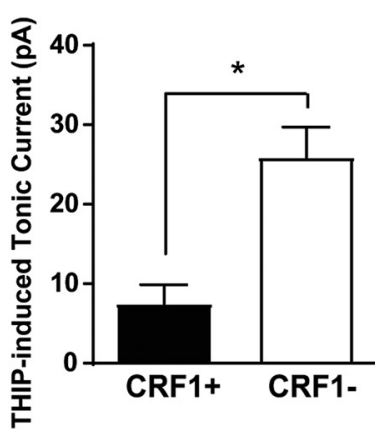

C

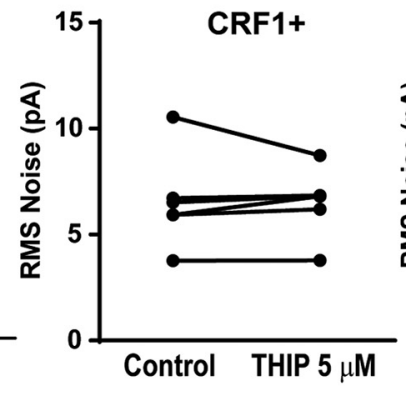

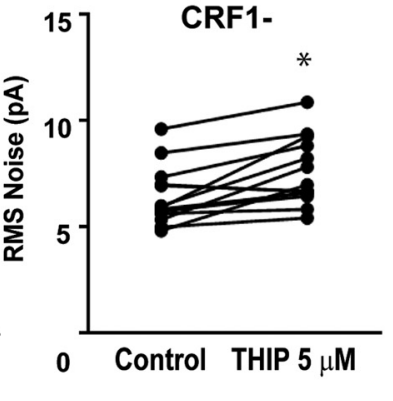

Figure 6. Contribution of $\delta$ subunit-containing $\mathrm{GABA}_{\mathrm{A}}$ receptors to tonic conductance in $\mathrm{CRF}^{+}{ }^{+}$and $\mathrm{CRF}^{-}$lateral amygdala neurons. $\boldsymbol{A}$, Representative voltage-clamp recording of a $\mathrm{CRF}^{+}{ }^{+}$(left) and $\mathrm{CRF}^{-}$(right) cell during superfusion of the $\delta$ subunit-preferring GABA $A_{A}$ agonist THIP $(5 \mu \mathrm{M})$. White dashed line indicates level of holding current before and after THIP superfusion. $\boldsymbol{B}$, Summary of the tonic current induced by THIP in CRF $1^{+}$and $\mathrm{CRF} 1^{-}$cells; $* p<0.05$ by unpaired $t$ test comparing $\mathrm{CRF} 1^{+}$to CRF1- cells. C, Summary of the change in rms noise induced by THIP superfusion in CRF1 ${ }^{+}$(left) and $\mathrm{CRF}^{-}{ }^{-}$(right) cells. ${ }^{*} p<0.05$ by paired $t$ test comparing differences between control and THIP $5 \mu \mathrm{m}$

$\mathrm{CRF}^{+}$neurons $(7.5 \pm 2.4 \mathrm{pA} ; n=6$ cells from 6 mice; $t_{(5)}=3.12, p=0.0262$ by one-sample $t$ test; Fig. $6 A$, left, $B$ ) and $\mathrm{CRF}^{-}$neurons $(25.9 \pm 3.8 \mathrm{pA} ; n=14$ cells from 10 mice; $t_{(13)}=6.82, p<0.001$ by one-sample $t$ test; Fig. $6 A$, right trace, $B)$. This increase was significantly greater in CRF1 $1^{-}$neurons compared with $\mathrm{CRF} 1^{+}$neurons $\left(t_{(18)}=3.03\right.$, $* p=0.0072$ by unpaired $t$ test; $18.44 \pm 6.09 \mathrm{pA}$ effect size; $95 \%$ confidence interval, -31.24 to -5.65$)$. Consistent with the observed effects on holding current, focal application of THIP onto $\mathrm{CRF}^{+}{ }^{+}$neurons resulted in no change in the amplitude of the holding current or rms noise $(6.6 \pm 0.9-$ $6.5 \pm 0.7 \mathrm{pA}$; Fig. $6 C$, left; $p=0.9183$ by paired $t$ test) but significantly increased rms noise in $\mathrm{CRF}^{-}$neurons $\left(6.4 \pm 0.4-7.5 \pm 0.4 \mathrm{pA}\right.$; Fig. $6 C$, right; $t_{(13)}=4.03, p=$ 0.0014 by paired $t$ test; $1.16 \pm 0.29 \mathrm{pA}$ effect size; $95 \%$ confidence interval, -1.78 to -0.54$)$. Together, these findings indicate that the $\delta$ subunit is expressed predominantly in $\mathrm{CRF}^{-}$neurons, whereas the $\alpha 1$ subunit is expressed predominantly in $\mathrm{CRF} 1^{+}$neurons, and that $\delta$-containing $\mathrm{GABA}_{\mathrm{A}}$ receptors contribute to tonic conductance in $\mathrm{CRF}^{-}{ }^{-}$but not $\mathrm{CRF} 1^{+}$neurons.

\section{Acute cellular ethanol exposure}

GABA $_{A}$ receptors are sensitive to ethanol, and tonic conductance has been shown to be selectively augmented by acute ethanol (Wallner et al., 2003; Wei et al., 2004; Herman et al., 2013). Focal application of EtOH (44
$\mathrm{mM}$ ) did not significantly alter sIPSC interevent interval or sIPSC frequency ( $107 \pm 4.0 \%$ of control; $p=0.1514$ by one-sample $t$ test; $n=5$ cells from five mice; Fig. $7 A, C$, top) in $\mathrm{CRF} 1^{+}$neurons, but decreased interevent interval and increased sIPSC frequency in $\mathrm{CRF}^{-}$neurons (121.1 $\pm 1.3 \%$ of control; $n=5$ cells from five mice; Fig. $7 B, C$, top; $t_{(3)}=15.82, * p=0.0005$ by one-sample $t$ test; $t_{(7)}=3.03, \# p=0.01,915$ by unpaired $t$ test; $14.08 \pm 4.65 \%$ control effect size; $95 \%$ confidence interval, -25.08 to -3.09). Ethanol did not change sIPSC amplitude $(97.76 \pm 4.8 \%$ and $100.1 \pm 4.3 \%$ of control, $p=0.7285$ by unpaired $t$ test; Fig. $7 C$, bottom), rise $(105.0 \pm 5.8 \%$ and $105.6 \pm 2.1 \%$ of control, $p=0.9222$ by unpaired $t$ test), or decay $(104.5 \pm 2.8 \%$ and $103.3 \pm 2.2 \%$ of control, $p=0.7395$ by unpaired $t$ test) in $\mathrm{CRF}^{+}$or $\mathrm{CRF}^{-}$neurons, respectively. Additionally, focal application of ethanol did not significantly change the holding current of $\mathrm{CRF}^{+}{ }^{+}$neurons $(1.2 \pm 0.9 \mathrm{pA}, n=5$ cells from five mice; Fig. $7 D, F ; p=0.2304$ by one-sample $t$ test), but did significantly increase holding current in $\mathrm{CRF}^{-}$neurons $\left(12.6 \pm 0.9 \mathrm{pA}, t_{(4)}=14.11, * p=0.0001\right.$ by one-sample $t$ test, $n=5$ cells from five mice; $t_{(8)}=9.09, \# p=0.0001$ by unpaired $t$ test; $11.37 \pm 1.25 \mathrm{pA}$ effect size; $95 \%$ confidence interval, -14.26 to -8.487 ; Fig. $7 E, F)$. Acute ethanol did not significantly affect rms noise in $\mathrm{CRF}^{+}$ neurons $(5.9 \pm 0.2 \mathrm{pA}$ at baseline to $6.1 \pm 0.4 \mathrm{pA}$ after $\mathrm{EtOH}, p=0.3868)$ or $\mathrm{CRF}^{-}$neurons $(6.3 \pm 0.5 \mathrm{pA}$ at baseline to $6.2 \pm 0.5 \mathrm{pA}$ after $\mathrm{EtOH}, p=0.6131$ ). 
A

CRF1+

Control

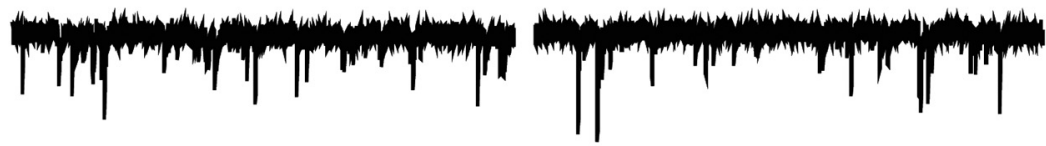

EtOH 44 mM

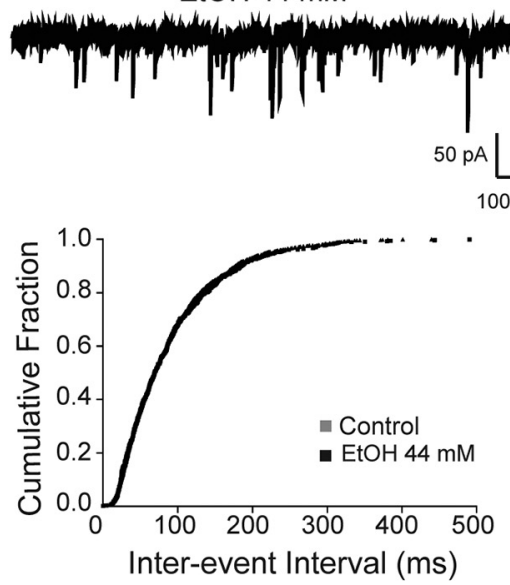

D

\section{CRF1+}

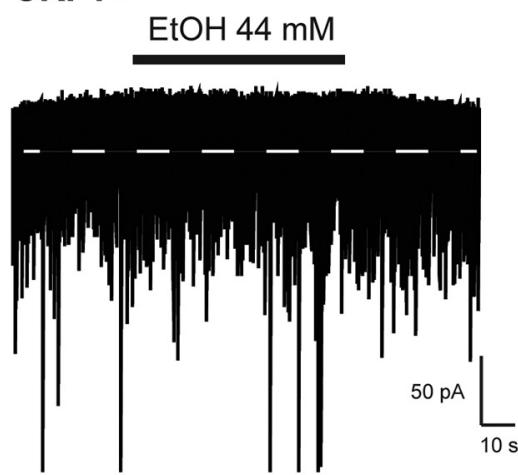

B

CRF1-

EtOH $44 \mathrm{mM}$

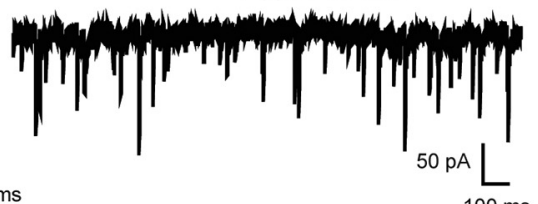

$100 \mathrm{~ms}$

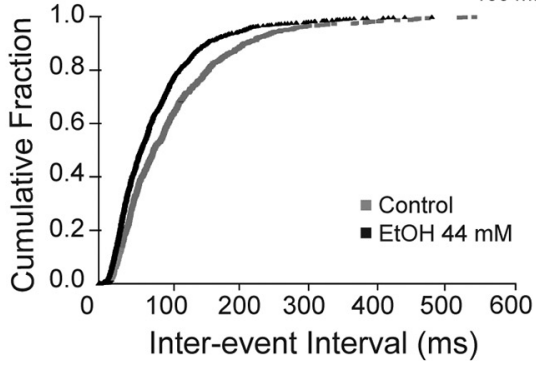

E

\section{CRF1-}

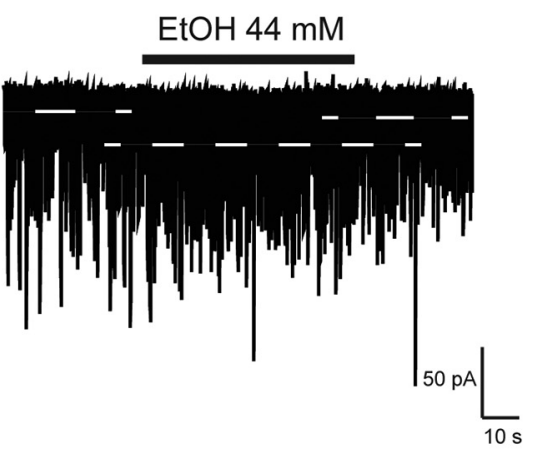

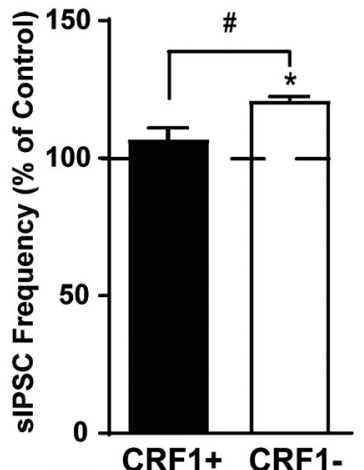

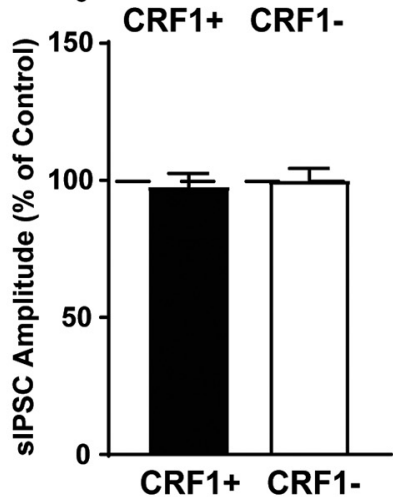

$\mathbf{F}$

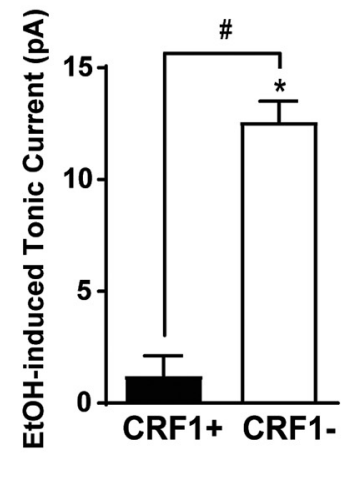

Figure 7. Effects of acute ethanol exposure on phasic and tonic inhibitory transmission in $\mathrm{CRF}^{+}$and $\mathrm{CRF}^{-}{ }^{-}$lateral amygdala neurons. $\boldsymbol{A}$, Representative voltage-clamp recording (top) and cumulative probability histogram of interevent interval (bottom) of a $\mathrm{CRF}^{+}{ }^{+}$cell during superfusion of $\mathrm{EtOH}(44 \mathrm{~mm})$. $\boldsymbol{B}$, Representative voltage-clamp recording (top) and cumulative probability histogram of interevent interval (bottom) of a $\mathrm{CRF}^{-}$cell during superfusion of $\mathrm{EtOH}(44 \mathrm{~mm})$. $\boldsymbol{C}$, Summary of the change in sIPSC frequency (top) and amplitude (bottom) following ethanol superfusion compared with baseline in $\mathrm{CRF} 1^{+}$and $\mathrm{CRF} 1^{-}$cells. $* p<0.05$ by one-sample $t$ test comparing differences from baseline within cell type; \#p $<0.05$ by unpaired $t$ test comparing CRF1 $1^{+}$to $\mathrm{CRF}^{-}$ cells. $\boldsymbol{D}$, Representative voltage-clamp recording of a $\mathrm{CRF}^{+}$cell during superfusion of EtOH $(44 \mathrm{~mm})$. White dashed line indicates the level of holding current before and after $\mathrm{EtOH}$ superfusion. $\boldsymbol{E}$, Representative voltage-clamp recording of a $\mathrm{CRF}^{-}{ }^{-}$cell during superfusion of $\mathrm{EtOH}(44 \mathrm{~mm})$. White dashed line indicates the level of holding current before and after EtOH superfusion. $\boldsymbol{F}$, Summary of the tonic current induced by ethanol in $\mathrm{CRF}^{+}$and $\mathrm{CRF} 1^{-}$cells. $* p<0.05$ by one-sample $t$ test comparing differences from baseline within cell type; $\# p<0.05$ by unpaired $t$ test comparing $\mathrm{CRF}^{+}{ }^{+}$to $\mathrm{CRF} 1^{-}$cells.

\section{Chronic intermittent ethanol exposure}

To examine the sensitivity of LA neurons to chronic ethanol exposure, we subjected CRF1:GFP mice to CIE vapor exposure (4-5 weeks) and CIE followed by 3-7 d of withdrawal (CIE-WD). There were no significant changes in membrane properties in $\mathrm{CRF}^{+}$neurons following ethanol vapor exposure or withdrawal (Fig. 8A), and, consistent with naive neurons, the majority of $\mathrm{CRF}^{+}$neurons from AIR, CIE, and CIE-WD mice exhibited spike accommodation (Fig. 8B). Rheobase was reduced in $\mathrm{CRF}^{+}$ neurons from CIE mice $(74.74 \pm 8.63 \mathrm{pA}, n=19$ cells from 11 mice) compared with neurons from AIR mice (46.15 \pm $5.72 \mathrm{pA}, n=19$ cells from 6 mice; $t_{(30)}=2.49, p=0.0187$ by unpaired $t$ test; effect size, $-28.58 \pm 11.49 \mathrm{pA} ; 95 \%$ confidence interval, -52.05 to -5.113 ; Fig. $8 C$, left). Rheobase did not significantly differ between $\mathrm{CRF} 1^{+}$neurons from 


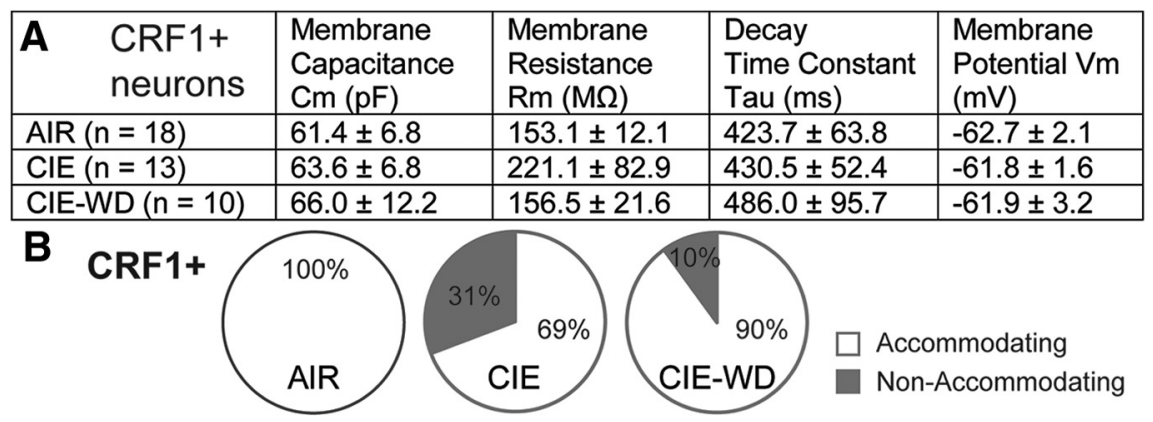

C



D

\begin{tabular}{|l|l|l|l|l|}
\hline $\begin{array}{c}\text { CRF1- } \\
\text { neurons }\end{array}$ & $\begin{array}{l}\text { Membrane } \\
\text { Capacitance } \\
\mathrm{Cm}(\mathrm{pF})\end{array}$ & $\begin{array}{l}\text { Membrane } \\
\text { Resistance } \\
\mathrm{Rm}(\mathrm{M} \Omega)\end{array}$ & $\begin{array}{l}\text { Decay } \\
\text { Time Constant } \\
\text { Tau }(\mathrm{ms})\end{array}$ & $\begin{array}{l}\text { Membrane } \\
\text { Potential Vm } \\
(\mathrm{mV})\end{array}$ \\
\hline AIR $(\mathrm{n}=10)$ & $74.5 \pm 10.3$ & $164.3 \pm 30.2$ & $444.6 \pm 70.4$ & $-63.7 \pm 2.3$ \\
\hline $\mathrm{CIE}(\mathrm{n}=8)$ & $75.0 \pm 9.0$ & $119.0 \pm 12.2$ & $521.8 \pm 87.6$ & $-63.5 \pm 3.1$ \\
\hline CIE-WD $(\mathrm{n}=6)$ & $67.5 \pm 15.4$ & $152.0 \pm 29.1$ & $631.4 \pm 134.5$ & $-65.2 \pm 1.5$ \\
\hline
\end{tabular}

F CRF1-
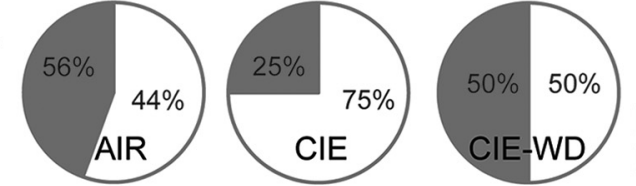

Accommodating

Non-Accommodating

G

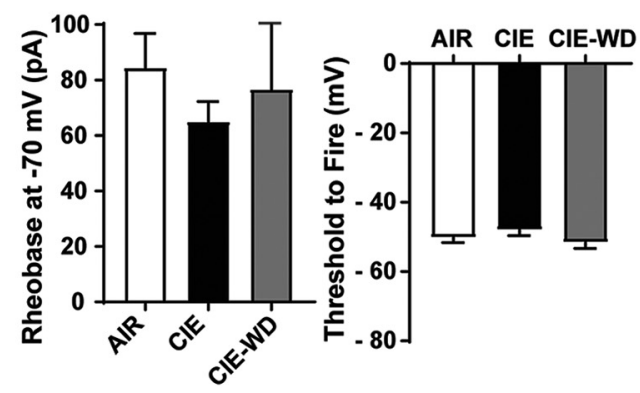

H

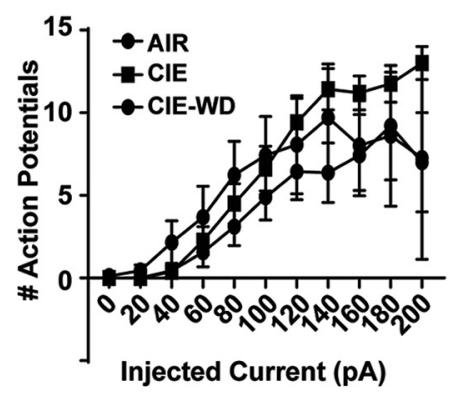

Figure 8. Effects of chronic ethanol vapor on membrane characteristics and excitability in $\mathrm{CRF} 1^{+}$and $\mathrm{CRF} 1^{-}$lateral amygdala neurons. $\boldsymbol{A}$, Summary of membrane characteristics of CRF1 ${ }^{+}$LA neurons from AIR, CIE, and CIE-WD mice. $\boldsymbol{B}$, Relative proportion of $\mathrm{CRF}^{+}{ }^{+}$neurons exhibiting spike accommodation from AIR (left), CIE (center), and CIE-WD (right) mice. $\boldsymbol{C}$, Summary of rheobase at $-70 \mathrm{mV}$ (left) and the threshold to fire (right) of CRF1 ${ }^{+}$neurons from AIR, CIE, and CIE-WD mice. $* p<0.05$ by unpaired $t$ test comparing $\mathrm{CRF}^{+}{ }^{+}$neurons from AIR mice to $\mathrm{CRF}^{+}{ }^{+}$neurons from CIE mice. $\boldsymbol{D}$, Summary of action potentials by current injection in $\mathrm{CRF}^{+}$neurons from AIR, CIE, and CIE-WD mice. $\boldsymbol{E}$, Summary of membrane characteristics of CRF1- LA neurons from AIR, CIE, and CIE-WD mice. $\boldsymbol{F}$, Relative proportion of CRF1- neurons exhibiting spike accommodation from AIR (left), CIE (middle), and CIE-WD (right) mice. G, Summary of rheobase at $-70 \mathrm{mV}$ (left) and the threshold to fire (right) of CRF1- neurons from AIR, CIE, and CIE-WD mice. $\boldsymbol{H}$, Summary of action potentials by current injection in CRF1- neurons from AIR, CIE, and CIE-WD mice.

CIE-WD mice (64 $\pm 11.85 \mathrm{pA}, n=10$ cells from three mice) and neurons from AIR mice ( $p=0.4708$; Fig. $8 C$, left). The threshold to fire was also reduced in neurons from CIE mice $(-58.58 \pm 2.35 \mathrm{mV})$ versus neurons from AIR mice $\left(-49.71 \pm 1.50 \mathrm{mV} ; t_{(30)}=3.34, p=0.0022\right.$ via unpaired $t$ test; effect size, $8.87 \pm 2.65 \mathrm{mV}$; $95 \%$ confidence intervals, -14.29 to -3.46 ; Fig. $8 \mathrm{C}$, right) but was not different in neurons from CIE-WD mice $(-52.43 \pm 2.55 \mathrm{mV})$ versus neurons from AIR mice $(p=0.3353)$. In addition, we found no differences in action potentials elicited by ascending 
A

CRF1+
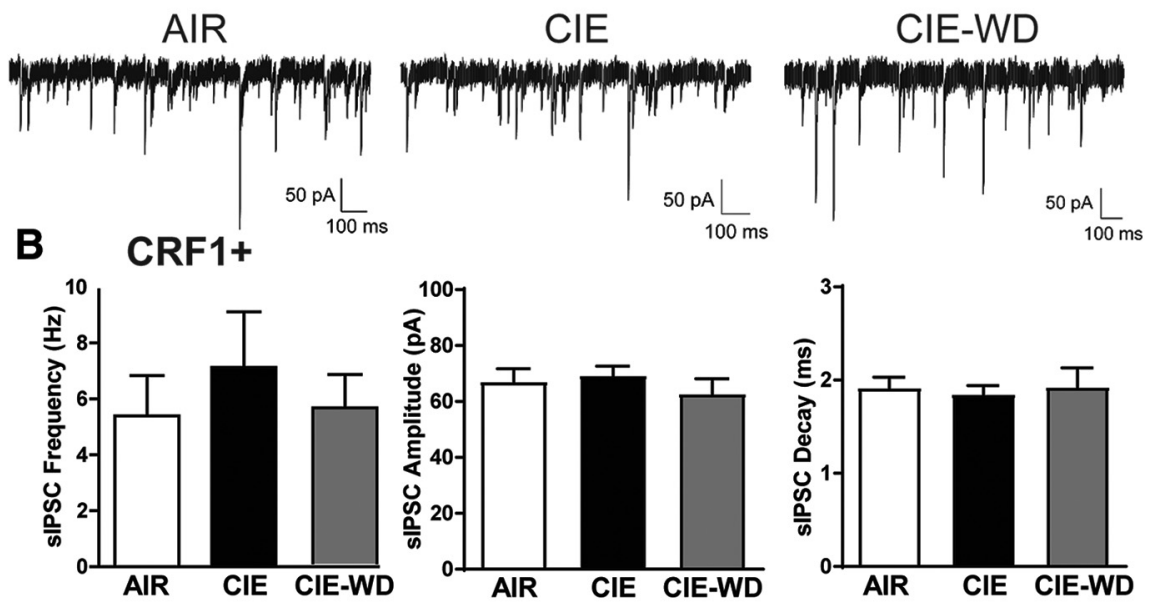

C CRF1-
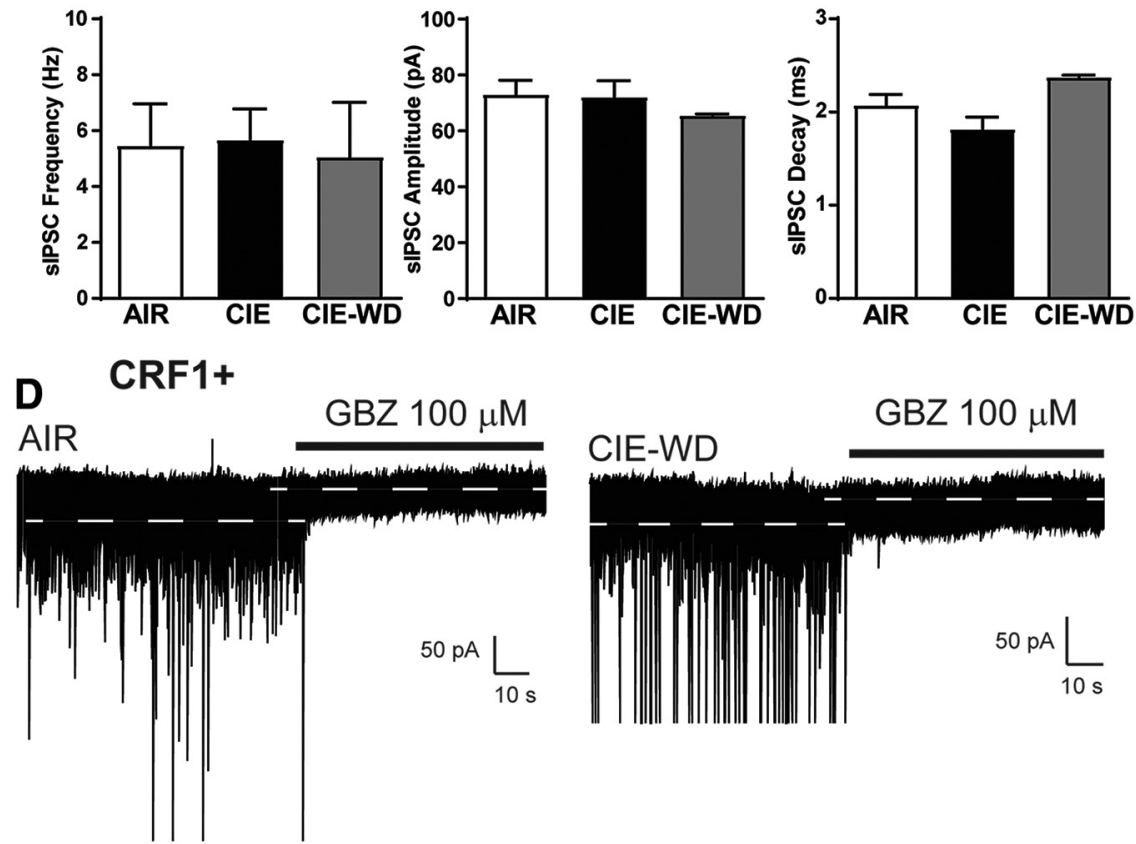

E
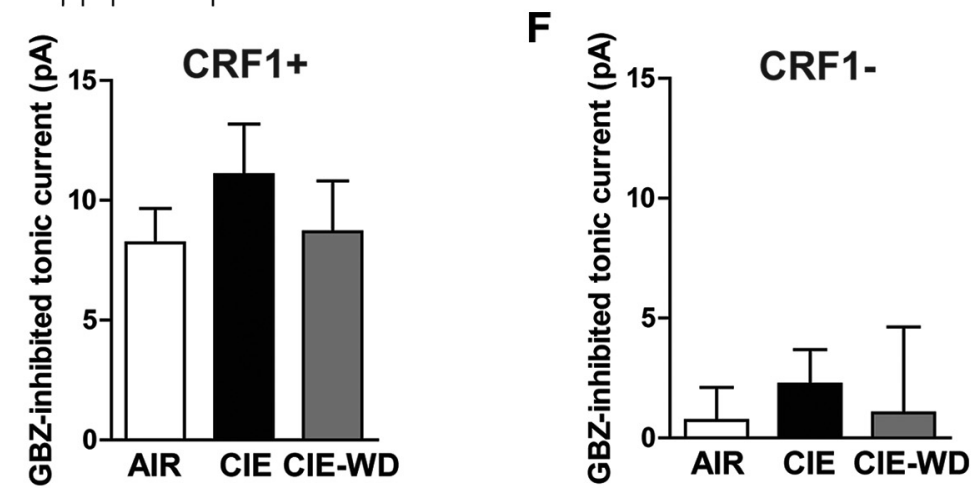

Figure 9. Effects of chronic ethanol vapor on phasic and tonic inhibitory transmission in $\mathrm{CRF} 1^{+}$and $\mathrm{CRF} 1^{-}$lateral amygdala neurons. $\boldsymbol{A}$, Representative voltage-clamp recordings of $\mathrm{CRF}^{+}{ }^{+}$neurons from AIR (left), CIE (center), and CIE-WD (right) mice. $\boldsymbol{B}$, Summary of sIPSC frequency (left), amplitude (middle), and decay (right) in CRF1 ${ }^{+}$neurons from AIR, CIE, and CIE-WD mice. $\boldsymbol{C}$, Summary of sIPSC frequency (left), amplitude (center), and decay (right) in CRF1- neurons from AIR, CIE, and CIE-WD mice. $\boldsymbol{D}$, Representative voltage-clamp recording of $\mathrm{CRF}^{+}{ }^{+}$cells from AIR (left) and CIE-WD (right) mice during GBZ superfusion (100 $\mu \mathrm{M}$ ). 
continued

White dashed line indicates the level of holding current before and after GBZ superfusion. $\boldsymbol{E}$, Summary of tonic current revealed by gabazine superfusion in $\mathrm{CRF} 1^{+}$cells. $\boldsymbol{F}$, Summary of tonic current revealed by gabazine superfusion in $\mathrm{CRF} 1^{-}$cells.

current injection among the three exposure conditions (Fig. 8D). Together, these findings indicate increases in the excitability of $\mathrm{LA} \mathrm{CRF}^{+}$neurons following CIE exposure that are normalized under withdrawal conditions.

There were no significant changes in membrane properties in $\mathrm{CRF}^{-}{ }^{-}$neurons following ethanol vapor exposure or withdrawal (Fig. 8E), and, consistent with neurons from naive mice, approximately half of $\mathrm{CRF}^{-}{ }^{-}$neurons from AIR and CIE-WD mice exhibited spike accommodation (Fig. 8F). No changes in rheobase were observed among $\mathrm{CRF}^{-}{ }^{-}$neurons from AIR mice $(84.44 \pm 12.37 \mathrm{pA}, n=9$ cells from four mice), CIE mice $(65.00 \pm 7.32 \mathrm{pA}, n=8$ cells from three mice), or CIE-WD mice (76.67 $\pm 26.03 \mathrm{pA}$, $n=6$ cells from three mice; Fig. 8G, left). The threshold to fire was also comparable in $\mathrm{CRF}^{-}$neurons from AIR mice $(-50.18 \pm 1.47 \mathrm{mV})$ versus neurons from CIE mice $(-48.00 \pm 1.62 \mathrm{mV})$ and CIE-WD mice $(-51.55 \pm 1.76 \mathrm{mV}$; Fig. $8 G$, right). No significant differences in the number of action potentials across current injection steps emerged among $\mathrm{CRF}^{-}{ }^{-}$neurons from AIR, CIE, or CIE-WD mice (Fig. $8 H$ ). These findings indicate no changes in the excitability of $\mathrm{CRF}^{-}$neurons following AIR, CIE, or CIE-WD exposure.

We next assessed phasic inhibitory transmission in $\mathrm{CRF}^{+}{ }^{+}$and $\mathrm{CRF}^{-}{ }^{-}$LA neurons following vapor exposure. There were no significant changes in SIPSC frequency $(5.4 \pm 1.4,7.1 \pm 2.0$, and $5.6 \pm 1.2 \mathrm{~Hz} ; p=0.7112$ by oneway ANOVA; $n=5-8$ cells from 3-4 mice/group; Fig. 9A, $B$, left), sIPSC amplitude $(67.0 \pm 4.7,69.2 \pm 3.4$, and $62.7 \pm 5.5 \mathrm{pA} ; p=0.6551$ by one-way ANOVA; $n=5-8$ cells from 3-4 mice/group; Fig. 9A,B, middle), sIPSC rise $(1.9 \pm 1.1,1.8 \pm 0.1$, and $1.9 \pm 0.2 \mathrm{~ms} ; p=0.8369$ by oneway ANOVA; $n=5-8$ cells from 3-4 mice/group; Fig. 9A), or sIPSC decay $(1.9 \pm 1.1,1.8 \pm 0.1$, and $1.9 \pm 0.2 \mathrm{~ms}$; $p=0.9120$ by one-way ANOVA; $n=5-8$ cells from $3-4$ mice/group; Fig. $9 A, B$, right) in $\mathrm{CRF}^{+}$neurons from AIR, $\mathrm{CIE}$, and CIE-WD mice, respectively. CRF1- neurons from AIR, CIE, or CIE-WD mice were similarly unaffected. SIPSC frequency $(5.4 \pm 1.5,5.7 \pm 1.1$, and $5.1 \pm 1.9 \mathrm{~Hz}$; $p=0.9761$ by one-way ANOVA; $n=3-7$ cells from 3 mice/ group; Fig. 9C, left), sIPSC amplitude (73.1 \pm 5.0, $72.2 \pm$ 5.8 , and $65.6 \pm 0.5 \mathrm{pA} ; p=0.7758$ by one-way ANOVA; $n=3-7$ cells from 3 mice/group; Fig. $9 C$, middle), sIPSC rise $(1.7 \pm 0.7,1.1 \pm 0.1$, and $1.0 \pm 0.1 ; p=0.6595$ by oneway ANOVA; $n=3-7$ cells from 3 mice/group), and SIPSC decay $(2.1 \pm 0.1,1.8 \pm 0.1$, and $2.4 \pm 0.1 \mathrm{~ms} ; p=0.0902$ by one-way ANOVA; $n=3-7$ cells from 3 mice/group; Fig. $9 C$, right) were all unchanged.

We also examined the tonic inhibitory conductance in $\mathrm{CRF}^{+}{ }^{+}$and $\mathrm{CRF}^{-}{ }^{-}$neurons after CIE and CIE-WD. Focal application of GBZ (100 $\mu \mathrm{m})$ produced a significant reduction in holding current that was not significantly different among $\mathrm{CRF}^{+}{ }^{+}$neurons from AIR, CIE, and CIE-WD mice $(8.2 \pm 1.4,11.1 \pm 2.1$, and $8.7 \pm 2.1 \mathrm{pA} ; p=0.5122$ by one-way ANOVA; $n=5-7$ cells from 3-4 mice/group; Fig. $9 D, E)$. GBZ $(100 \mu \mathrm{m})$ also produced a reduction in the amplitude of the holding current or rms noise that was not significantly different between $\mathrm{CRF}^{+}$neurons from AIR, $\mathrm{CIE}$, and CIE-WD mice (10.3 $\pm 0.5-8.8 \pm 0.6,9.6 \pm 0.7-$ $8.3 \pm 0.5$, and $9.3 \pm 0.7-8.5 \pm 0.9 \mathrm{pA} ; p=0.4238$ by oneway ANOVA; $n=5-7$ cells from $3-4$ mice/group]. Focal application of GBZ $(100 \mu \mathrm{m})$ produced no reduction in holding current in $\mathrm{CRF}^{-}$neurons from AIR, CIE, or CIEWD mice $(0.7 \pm 1.4,2.2 \pm 1.4$, and $1.0 \pm 3.6 \mathrm{pA} ; p=$ 0.7642 by one-way ANOVA; $n=3-7$ cells from 3 mice/ group; Fig. 9F), no difference in the magnitude of reduction in the amplitude of the holding current or rms noise $(10.0 \pm 0.7-9.1 \pm 0.6,10.2 \pm 0.9-8.8 \pm 0.4$, and $7.8 \pm 0.1-$ $6.6 \pm 0.4 \mathrm{pA} ; p=0.6785$ by one-way ANOVA; $n=3-7$ cells from $3 \mathrm{mice} / g$ roup) and no significant difference among the experimental groups. These data suggest that tonic inhibitory signaling in the LA is insensitive to chronic ethanol exposure and chronic ethanol exposure followed by withdrawal.

\section{In vivo microdialysis}

To evaluate baseline transmitter levels following chronic ethanol exposure and withdrawal, we performed in vivo microdialysis in CRF1:GFP mice exposed to AIR $(n=4)$ or CIE-WD $(n=7)$. Mice were implanted with $0.5 \mathrm{~mm}$ microdialysis probes (Fig. 10A) aimed at the LA. However, as some penetrance into BLA is possible, results are described as LA/BLA (Fig. 10B). There were no significant differences detected between AIR and CIE-WD mice in basal GABA levels $(9.2 \pm 2.1$ and $11.9 \pm 1.3 \mathrm{~nm} ; p=0.28$ by unpaired $t$ test; $n=4-7$; Fig. 10C). Acute administration of ethanol $(1 \mathrm{M})$ in the perfusate solution produced significant increases in LA/BLA GABA levels in both AIR and CIE-WD mice as assessed by two-way ANOVA of preethanol and postethanol reverse dialysis (exposure condition $\times$ time) with a significant main effect of time $\left(F_{(11,99)}=\right.$ $5.585, p=0.0001)$, but no significant effect of exposure condition or interaction of time and exposure condition (Fig. 10D). There were also no significant differences detected between AIR and CIE-WD mice in basal glutamate levels $(1264 \pm 310.5$ and $1061 \pm 295.8 \mathrm{~nm} ; p=0.67 ; n=4-$ 7; Fig. 10E). Acute administration of ethanol (1 $\mathrm{m}$ in the perfusate solution) produced significant increases in LA BLA glutamate levels in both AIR and CIE-WD mice as assessed by two-way ANOVA of pre-ethanol and postethanol reverse dialysis (exposure condition $\times$ time) with a significant main effect of time $\left(F_{(11,99)}=4.747, p=0.0001\right)$, but no significant effect of exposure condition or interaction of time and exposure condition (Fig. 10F). These data suggest that baseline excitatory and inhibitory transmitter levels in the LA/BLA are not significantly altered by chronic ethanol exposure and withdrawal, and that the responsivity of these transmitter systems to ethanol also remains intact following chronic ethanol exposure and withdrawal. 

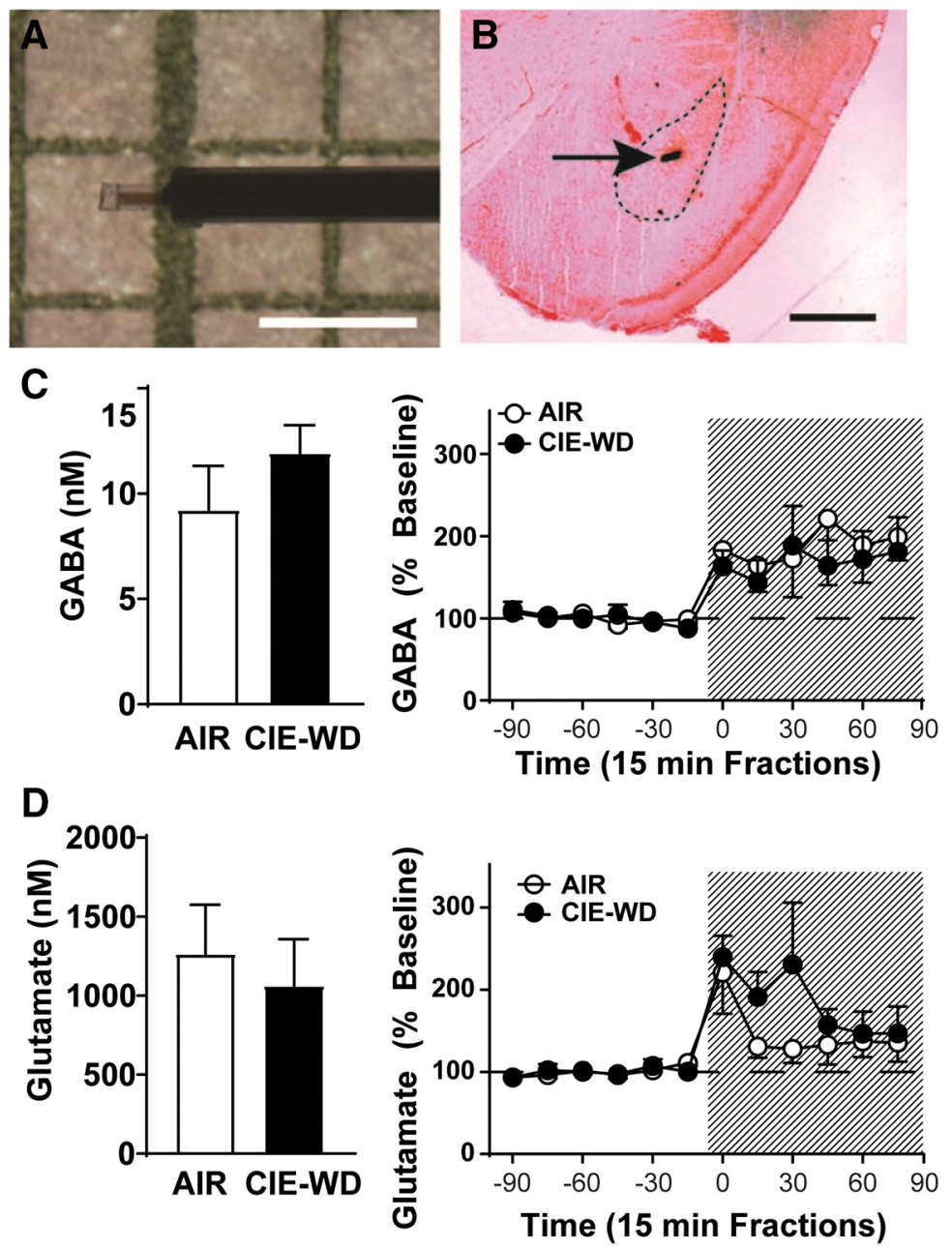

Figure 10. Effects of chronic ethanol vapor and withdrawal on exogenous GABA and glutamate concentration and sensitivity to acute ethanol in lateral amygdala/basolateral amygdala. $\boldsymbol{A}$, Representative microdialysis probe $(0.5 \mathrm{~mm})$. Scale bar, $1 \mathrm{~mm}$. $\boldsymbol{B}$, Histologic verification of probe site. Dashed lines indicate LA/BLA. Scale bar, $1 \mathrm{~mm}$. $\boldsymbol{C}$, Baseline dialysate concentrations of GABA (nM, left) and percent change in GABAergic transmission over time and following reverse dialysis of ehthanol (1 M, shaded area; right) in the LA/BLA of AIR and CIE-WD mice $(n=4-7)$. $D$, Baseline dialysate concentrations of glutamate (nM, left) and percent change in glutamatergic transmission over time and following reverse dialysis of ehthanol (1 M, shaded area; right) in the LA/BLA of AIR and CIE-WD mice $(n=4-7)$.

\section{Discussion}

The CRF1 system in the amygdala has been shown to play an important role in the development of ethanol dependence, but the $\mathrm{CRF} 1^{-}$-containing neuronal population specifically within the LA has not been fully characterized. Here, we report that $\mathrm{CRF}^{+}{ }^{+}$neurons in the LA are composed of multiple subgroups, including a small percentage of neurons expressing calcium binding proteins and a larger percentage of glutamatergic neurons. $\mathrm{CRF}^{+}$neurons exhibit distinct membrane properties, minor differences in baseline excitability, and possess an ongoing tonic $\mathrm{GABA}_{\mathrm{A}}$ receptor conductance that $\mathrm{CRF}^{-}$neurons lack. Acute ethanol exposure increases the inhibition of $\mathrm{CRF} 1^{-}$ neurons, but the inhibitory control of $\mathrm{CRF}^{+}{ }^{+}$neurons is insensitive to acute ethanol. $\mathrm{CRF}^{+}$neurons displayed increased excitability following chronic ethanol; however, neither $\mathrm{CRF}^{+}{ }^{+}$nor $\mathrm{CRF}^{-}{ }^{-}$LA cells displayed alterations in phasic or tonic GABAergic synaptic transmission following chronic ethanol exposure or withdrawal, and basal changes in extracellular GABA or glutamate levels were not observed between exposure groups. Collectively, these results suggest that CRF1 ${ }^{-}$LA neurons are sensitive to acute ethanol but that changes in $\mathrm{CRF}^{+}{ }^{+}$neuronal excitability following chronic ethanol are not due to neuroplastic changes in inhibitory control.

Both phasic and tonic GABAergic signaling regulate the activity and output of amygdala neurons. CRF1 ${ }^{+}$LA cells exhibit heightened basal phasic GABAergic signaling compared with $\mathrm{CRF}^{-}$cells and an ongoing tonic conductance that $\mathrm{CRF}^{-}$cells lack. Subunit stoichiometry regulates the ability of $\mathrm{GABA}_{\mathrm{A}}$ receptors to mediate tonic inhibition, with the $\delta, \alpha 5$, and $\varepsilon$ subunits imparting sensitivity of GABA $A_{A}$ receptors to low levels of GABA that are thought to underlie tonic conductance (Stell and Mody, 2002; Stell et al., 2003; Glykys and Mody, 2007).The results of the immunohistochemical studies indicate that 
$\mathrm{CRF}^{+}$cells predominantly express the $\alpha 1$ subunit and exhibit little colocalization with the $\delta$ subunit, consistent with previous reports (Wiltgen et al., 2009). Consistent with this observation, the tonic conductance seen in this population was insensitive to application of the $\delta$-preferring $\mathrm{GABA}_{\mathrm{A}}$ receptor agonist THIP. The tonic $\mathrm{GABA}_{\mathrm{A}}$ receptors in $\mathrm{CRF}^{+}{ }^{+}$cells of the LA therefore do not contain $\delta$ subunits but may contain alternative subunit stoichiometry, such as $\alpha 1 \beta 2 \gamma 2$ or $\alpha 5 \beta \gamma 2$. In the CeA, the tonic conductance exhibited by $\mathrm{CRF} 1^{+}$neurons was enhanced by the application of the preferential $\alpha 1 \mathrm{GABA}_{\mathrm{A}}$ agonist zolpidem, suggesting a role for $\alpha 1$-containing $\mathrm{GABA}_{\mathrm{A}}$ receptors in tonic inhibition in that population. A similar mechanism may regulate tonic conductance in $\mathrm{LA} \mathrm{CRF1}^{+}$ neurons. The $\delta$ subunit was sparsely expressed in unlabeled LA cells, as seen previously (Pirker et al., 2000), and a tonic conductance in $\mathrm{CRF}^{-}{ }^{-}$neurons was stimulated by acute application of THIP. These findings suggest that $\mathrm{CRF}^{-}{ }^{-}$cells express $\delta$ subunit-containing $\mathrm{GABA}_{\mathrm{A}}$ receptors that are not active under basal conditions but may be stimulated by agonist activity or heightened concentrations of extracellular GABA.

Previous research has assessed the effects of ethanol on inhibitory signaling within the LA/BLA broadly, but the effects of ethanol on GABAergic signaling and within specific $\mathrm{CRF}^{+}$and $\mathrm{CRF1}^{-}$populations have not been previously assessed. We observed that $\mathrm{CRF}^{+}$cells are relatively insensitive to changes in inhibitory control induced by acute ethanol; focal application failed to elicit a change in either phasic or tonic inhibitory signaling in this population. As $\mathrm{CRF}^{+}{ }^{+}$neurons exhibited heightened phasic and tonic $\mathrm{GABA}_{\mathrm{A}}$ signaling, these results may suggest a ceiling effect that precludes the possibility of GABA mimetics such as ethanol from further increasing sIPSC frequency or reducing holding current. In contrast, $\mathrm{CRF}^{-}$ cells demonstrated an increased tonic conductance in the presence of ethanol coupled with a significant increase in GABA release onto these cells. These differences in sensitivity to acute ethanol may be related to $\mathrm{GABA}_{\mathrm{A}}$ subunit expression differences between the two populations. $\delta$-Containing $\mathrm{GABA}_{\mathrm{A}}$ receptors have heightened sensitivity to ethanol (Wallner et al., 2003; Wei et al., 2004), and the $\delta$-expressing $\mathrm{CRF}^{-}$neurons exhibited increases in tonic inhibitory control in response to ethanol that the $\delta$-lacking $\mathrm{CRF}^{+}{ }^{+}$cells failed to demonstrate. The insensitivity of $\mathrm{CRF}^{+}$cells to acute ethanol was also observed in the CeA (Herman et al., 2013), suggesting that this population may have similar $\mathrm{GABA}_{\mathrm{A}}$ receptor compositions in multiple amygdala nuclei.

In contrast to the selective effects of acute ethanol, both phasic and tonic $\mathrm{GABA}_{\mathrm{A}}$ signaling in $\mathrm{LA} \mathrm{CRF1}{ }^{+}$and $\mathrm{CRF}^{-}$cells were not affected by chronic ethanol exposure or ethanol exposure and withdrawal. The microdialysis experiments showed that chronic ethanol and withdrawal did not produce adaptations in extracellular GABA or glutamate levels, which may explain the insensitivity of tonic conductance in $\mathrm{CRF}^{-}$neurons to ethanolinduced adaptations. Chronic ethanol exposure has been shown to increase basal GABA concentration in the CeA (Roberto et al., 2004a), elevating ambient GABA that is thought to drive cell type-specific changes in inhibitory control (Herman et al., 2016). Although the GABA $\mathrm{G}_{\mathrm{A}}$ receptor subunits associated with $\mathrm{CRF}^{+}$and $\mathrm{CRF}^{-}$neurons in the CeA and LA are similar, the lack of elevated ambient GABA in the LA likely precludes any chronic ethanol-induced plasticity in inhibitory signaling in either $\mathrm{CRF} 1^{+}$or $\mathrm{CRF}^{-}{ }^{-}$LA neurons. Together, these findings may suggest that, unlike the $\mathrm{CeA}$, inhibitory control of $\mathrm{CRF}^{+}{ }^{+}$neurons in the LA is relatively preserved following chronic ethanol exposure.

Importantly, following chronic ethanol exposure CRF1 ${ }^{+}$ neurons displayed reductions in the rheobase and threshold to fire, indicating increased excitability of $\mathrm{CRF}^{+}{ }^{+}$neurons but not $\mathrm{CRF}^{-}$neurons. Thus, although inhibitory signaling in the $\mathrm{CRF}^{+}{ }^{+}$population is relatively insensitive to the effects of acute ethanol, it is sensitive to chronic ethanol in multiple amygdala nuclei (the CeA and LA), making the $\mathrm{CRF}^{+}$population an important target for the actions of ethanol broadly within the amygdala. The results of the voltage-clamp experiments suggest that this enhanced excitability in the $\mathrm{CRF}^{+}$population is not driven by alterations in GABAergic signaling, which may indicate that these changes are instead regulated by ethanol-induced alterations in intrinsic excitability within the LA. Plasticity in glutamatergic signaling within the LA/BLA has been reported following chronic ethanol exposure (McCool et al., 2010), and the LA specifically exhibits alterations in molecular markers of glutamate signaling following chronic ethanol exposure in nonhuman primates (Alexander et al., 2018) and reinstatement of alcohol seeking in mice (Salling et al., 2017). Future work to characterize glutamatergic signaling in the $\mathrm{CRF}^{+}$and $\mathrm{CRF}^{-}$ populations of the LA both under basal conditions and following chronic ethanol exposure would help to clarify the mechanisms underlying these ethanol-induced changes in excitability.

In the chronic vapor exposure experiments, we did not find evidence for increased baseline phasic GABAergic signaling in $\mathrm{CRF}^{+}{ }^{+}$versus $\mathrm{CRF} 1^{-}$cells that was observed in our experiments with\& naive mice. The baseline sIPSC frequency in $\mathrm{CRF}^{+}{ }^{+}$neurons from AIR, CIE, and CIE-WD mice was lower than what was observed in $\mathrm{CRF}^{+}$neurons from naive mice and higher in $\mathrm{CRF}^{-}$neurons from AIR, CIE, and CIE-WD mice (Figs. $4 A, B, 9 B, C$ ), collectively leading to a loss of significant differences between the two cell populations in the chronic ethanol exposure experiments. As our data indicate that the $\mathrm{CRF}^{+}{ }^{+}$cell population is composed of a majority of glutamatergic principal neurons and a smaller subpopulation of interneurons, it is possible that differences in cell subpopulations sampled between the two experiments could account for these different baseline characteristics. However, we did observe tonic inhibition in the $\mathrm{CRF}^{+}$population and not the $\mathrm{CRF}^{-}$population in slices from both naive and vapor-exposed mice, which suggests that a similar population of cells was sampled in both sets of experiments. The loss of population differences in phasic but not tonic inhibition may be attributable to the stress of repeated injection, as the air-exposed mice were given daily pyrazole injections as a control for the treatment given to the CIE and CIE- 
WD groups. It is also possible that exposure to the air chamber, which as a novel environment may be a mild stressor, contributed to the differences between naive and AIR mice in these experiments. The relative sensitivity of phasic and tonic inhibitory control in $\mathrm{CRF}^{+}{ }^{+}$cells to repeated mild stress is an interesting avenue for future studies to explore.

Together, these findings suggest that, unlike adaptations in inhibitory control exhibited by other amygdala nuclei (notably the CeA), GABAergic signaling within the LA is intact despite chronic ethanol exposure and/or withdrawal. This resistance to ethanol-induced plasticity in inhibitory control within the LA may play a significant role in the development of alcohol dependence and alcohol use disorders. Sensory information, including external drug cues and internal states such as craving and withdrawal, is relayed first to the LA from the cortex and thalamus; glutamatergic projections from the LA then synapse with $\mathrm{CeA}, \mathrm{BLA}$ and lateral paracapsular neurons. Our findings suggest that, despite chronic ethanol exposure, inhibitory control of LA CRF $1^{+}$neurons (many of which are projection neurons) remains unchanged, allowing these cells to communicate with downstream amygdalar regions unimpeded. This suggests that neuroadaptations developing in the CeA (Herman et al., 2016) and BLA (Läck et al., 2007; Diaz et al., 2011) on chronic ethanol exposure result from local, intrinsic changes rather than from changes in extrinsic inputs from the LA. These findings may have relevance to amygdala circuitry in other contexts, such as fear learning, and may provide insights into other diseases involving amygdala dysfunction, including anxiety and depression. These findings also highlight the heterogeneous cell types within the LA and underscore the need for further cell type-specific characterization of amygdala physiology and pathology.

\section{References}

Agoglia AE, Herman MA (2018) The center of the emotional universe: alcohol, stress, and CRF1 amygdala circuitry. Alcohol 72:61-73.

Alexander NJ, Rau AR, Jimenez VA, Daunais JB, Grant KA, McCool BA (2018) SNARE complex-associated proteins in the lateral amygdala of Macaca mulatta following long-term ethanol drinking. Alcohol Clin Exp Res 42:1661-1673.

Baur R, Kaur KH, Sigel E (2009) Structure of alpha6 beta3 delta GABA(A) receptors and their lack of ethanol sensitivity. J Neurochem 111:1172-1181.

Belelli D, Harrison NL, Maguire J, Macdonald RL, Walker MC, Cope

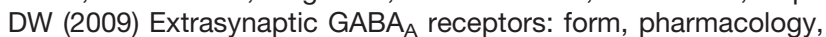
and function. J Neurosci 29:12757-12763.

Borghese CM, Harris RA (2007) Studies of ethanol actions on recombinant delta-containing gamma-aminobutyric acid type $A$ receptors yield contradictory results. Alcohol 41:155-162.

Buczynski MW, Herman MA, Hsu KL, Natividad LA, Irimia C, Polis IY, Pugh H, Chang JW, Niphakis MJ, Cravatt BF, Roberto M, Parsons LH (2016) Diacylglycerol lipase disinhibits VTA dopamine neurons during chronic nicotine exposure. Proc Natl Acad Sci U S A 113:1086-1091.

Calakos KC, Blackman D, Schulz AM, Bauer EP (2017) Distribution of type I corticotropin-releasing factor (CRF1) receptors on GABAergic neurons within the basolateral amygdala. Synapse 71: e21953.

Diaz MR, Christian DT, Anderson NJ, McCool BA (2011) Chronic ethanol and withdrawal differentially modulate lateral/basolateral amygdala paracapsular and local GABAergic synapses. J Pharmacol Exp Ther 337:162-170.

Eckardt MJ, File SE, Gessa GL, Grant KA, Guerri C, Hoffman PL, Kalant H, Koob GF, Li TK, Tabakoff B (1998) Effects of moderate alcohol consumption on the central nervous system. Alcohol Clin Exp Res 22:998-1040.

Glykys J, Mody I (2007) Activation of GABAA receptors: views from outside the synaptic cleft. Neuron 56:763-770.

Grobin AC, Matthews DB, Devaud LL, Morrow AL (1998) The role of $\operatorname{GABA}(A)$ receptors in the acute and chronic effects of ethanol. Psychopharmacology (Berl) 139:2-19.

Herman MA, Contet C, Justice NJ, Vale W, Roberto M (2013) Novel subunit-specific tonic GABA currents and differential effects of ethanol in the central amygdala of CRF receptor-1 reporter mice. $J$ Neurosci 33:3284-3298.

Herman MA, Contet C, Roberto M (2016) A functional switch in tonic GABA currents alters the output of central amygdala corticotropin releasing factor receptor- 1 neurons following chronic ethanol exposure. J Neurosci 36:10729-10741.

Hubbard DT, Nakashima BR, Lee I, Takahashi LK (2007) Activation of basolateral amygdala corticotropin-releasing factor 1 receptors modulates the consolidation of contextual fear. Neuroscience 150:818-828.

Justice NJ, Yuan ZF, Sawchenko PE, Vale W (2008) Type 1 corticotropin-releasing factor receptor expression reported in BAC transgenic mice: implications for reconciling ligand-receptor mismatch in the central corticotropin-releasing factor system. J Comp Neur 511:479-496.

Koob GF, Roberts AJ, Schulteis G, Parsons LH, Heyser CJ, Hyytiä P, Merlo-Pich E, Weiss F (1998) Neurocircuitry targets in ethanol reward and dependence. Alcohol Clin Exp Res 22:3-9.

Krook-Magnuson El, Huntsman MM (2005) Excitability of cortical neurons depends upon a powerful tonic conductance in inhibitory networks. Thalamus Relat Syst 3:115-120.

Läck AK, Diaz MR, Chappell A, DuBois DW, McCool BA (2007) Chronic ethanol and withdrawal differentially modulate pre- and postsynaptic function at glutamatergic synapses in rat basolateral amygdala. J Neurophysiol 98:3185-3196.

Lovinger DM, Roberto M (2013) Synaptic effects induced by alcohol. Curr Top Behav Neurosci 13:31-86.

Marowsky A, Rudolph U, Fritschy JM, Arand M (2012) Tonic inhibition in principal cells of the amygdala: a central role for $\alpha 3$ subunit-

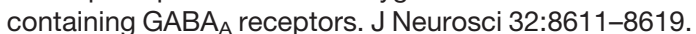

McCool BA, Christian DT, Diaz MR, Läck AK (2010) Glutamate plasticity in the drunken amygdala: the making of an anxious synapse. Int Rev Neurobiol 91:205-233.

Mody I, Glykys J, Wei W (2007) A new meaning for "Gin and Tonic": tonic inhibition as the target for ethanol action in the brain. Alcohol 41:145-153.

Nie Z, Schweitzer P, Roberts AJ, Madamba SG, Moore SD, Siggins GR (2004) Ethanol augments GABAergic transmission in the central amygdala via CRF1 receptors. Science 303:1512-1514.

Overstreet DH, Knapp DJ, Breese GR (2004) Modulation of multiple ethanol withdrawal-induced anxiety-like behavior by CRF and CRF1 receptors. Pharmacol Biochem Behav 77:405-413.

Pavon FJ, Serrano A, Sidhpura N, Polis I, Stouffer D, de Fonseca FR, Cravatt BF, Martin-Fardon R, Parsons LH (2018) Fatty acid amide hydrolase (FAAH) inactivation confers enhanced sensitivity to nicotine-induced dopamine release in the mouse nucleus accumbens. Addict Biol 23:723-734.

Pavon FJ, Serrano A, Stouffer DG, Polis I, Roberto M, Cravatt BF, Martin-Fardon R, Rodriguez de Fonseca F, Parsons LH (2019) Ethanol-induced alterations in endocannabinoids and relevant neurotransmitters in the nucleus accumbens of fatty acid amide hydrolase knockout mice. Addict Biol 24:1204-1215.

Pirker S, Schwarzer C, Wieselthaler A, Sieghart W, Sperk G (2000) GABA(A) receptors: immunocytochemical distribution of 13 subunits in the adult rat brain. Neuroscience 101:815-850. 
Pitkänen A, Savander V, LeDoux JE (1997) Organization of intraamygdaloid circuitries in the rat: an emerging framework for understanding functions of the amygdala. Trends Neurosci 20:517-523.

Rainnie DG, Bergeron R, Sajdyk TJ, Patil M, Gehlert DR, Shekhar A (2004) Corticotrophin releasing factor-induced synaptic plasticity in the amygdala translates stress into emotional disorders. J Neurosci 24:3471-3479.

Roberto M, Madamba SG, Stouffer DG, Parsons LH, Siggins GR (2004a) Increased GABA release in the central amygdala of ethanol-dependent rats. J Neurosci 24:10159-10166.

Roberto M, Schweitzer P, Madamba SG, Stouffer DG, Parsons LH, Siggins GR (2004b) Acute and chronic ethanol alter glutamatergic transmission in rat central amygdala: an in vitro and in vivo analysis. J Neurosci 24:1594-1603.

Roberto M, Cruz MT, Gilpin NW, Sabino V, Schweitzer P, Bajo M, Cottone P, Madamba SG, Stouffer DG, Zorrilla EP, Koob GF, Siggins GR, Parsons LH (2010) Corticotropin releasing factor-induced amygdala gamma-aminobutyric acid release plays a key role in alcohol dependence. Biol Psychiatry 67:831-839.

Rodrigues SM, Schafe GE, LeDoux JE (2004) Molecular mechanisms underlying emotional learning and memory in the lateral amygdala. Neuron 44:75-91.

Rostkowski AB, Leitermann RJ, Urban JH (2013) Differential activation of neuronal cell types in the basolateral amygdala by corticotropin releasing factor. Neuropeptides 47:273-280.

Sah P, Faber ES, Lopez De Armentia M, Power J (2003) The amygdaloid complex: anatomy and physiology. Physiol Rev 83:803-834.

Salling MC, Hodge CJ, Psilos KE, Eastman VR, Faccidomo SP, Hodge CW (2017) Cue-induced reinstatement of alcohol-seeking behavior is associated with increased CaMKII T286 phosphorylation in the reward pathway of mice. Pharmacol Biochem Behav 163:20-29.

Saxena NC, Macdonald RL (1996) Properties of putative cerebellar gamma-aminobutyric acid A receptor isoforms. Mol Pharmacol 49:567-579.

Sears RM, Schiff HC, LeDoux JE (2014) Molecular mechanisms of threat learning in the lateral nucleus of the amygdala. Prog Mol Biol TransI Sci 122:263-304.

Semyanov A, Walker MC, Kullmann DM, Silver RA (2004) Tonically active GABA A receptors: modulating gain and maintaining the tone. Trends Neurosci 27:262-269.
Song P, Mabrouk OS, Hershey ND, Kennedy RT (2012) In vivo neurochemical monitoring using benzoyl chloride derivatization and liquid chromatography-mass spectrometry. Anal Chem 84:412-419.

Sosulina L, Meis S, Seifert G, Steinhäuser C, Pape HC (2006) Classification of projection neurons and interneurons in the rat lateral amygdala based upon cluster analysis. Mol Cell Neurosci 33:57-67.

Stell BM, Mody I (2002) Receptors with different affinities mediate phasic and tonic $\mathrm{GABA}_{\mathrm{A}}$ conductances in hippocampal neurons. J Neurosci 22:RC223.

Stell BM, Brickley SG, Tang CY, Farrant M, Mody I (2003) Neuroactive steroids reduce neuronal excitability by selectively enhancing tonic inhibition mediated by delta subunit-containing GABAA receptors. Proc Natl Acad Sci U S A 100:14439-14444.

Tye KM, Prakash R, Kim SY, Fenno LE, Grosenick L, Zarabi H, Thompson KR, Gradinaru V, Ramakrishnan C, Deisseroth K (2011) Amygdala circuitry mediating reversible and bidirectional control of anxiety. Nature 471:358-362.

Ugolini A, Sokal DM, Arban R, Large CH (2008) CRF1 receptor activation increases the response of neurons in the basolateral nucleus of the amygdala to afferent stimulation. Front Behav Neurosci 2:2.

Van Pett K, Viau V, Bittencourt JC, Chan RK, Li HY, Arias C, Prins GS, Perrin M, Vale W, Sawchenko PE (2000) Distribution of mRNAs encoding CRF receptors in brain and pituitary of rat and mouse. J Comp Neurol 428:191-212.

Wallner M, Hanchar HJ, Olsen RW (2003) Ethanol enhances alpha 4 beta 3 delta and alpha 6 beta 3 delta gamma-aminobutyric acid type A receptors at low concentrations known to affect humans. Proc Natl Acad Sci U S A 100:15218-15223.

Wei W, Faria LC, Mody I (2004) Low ethanol concentrations selectively augment the tonic inhibition mediated by $\delta$ subunit-containing $\mathrm{GABA}_{\mathrm{A}}$ receptors in hippocampal neurons. J Neurosci 24:8379-8382.

Weiner JL, Valenzuela CF (2006) Ethanol modulation of GABAergic transmission: the view from the slice. Pharmacol Ther 111:533554.

Wiltgen BJ, Godsil BP, Peng Z, Saab F, June HL, Linn MLV, Cook JM, Houser CR, O'Dell TJ, Homanics GE, Fanselow MS (2009) The alpha1 subunit of the GABA(A) receptor modulates fear learning and plasticity in the lateral amygdala. Front Behav Neurosci 3:37. 